\title{
Role of NiMo Alloy and Ni Species in the Performance of NiMo/ Alumina Catalysts for Hydrodeoxygenation of Stearic Acid: A Kinetic Study
}

\author{
Pankaj Kumar, Sunil K. Maity,*(i) and Debaprasad Shee \\ Department of Chemical Engineering, Indian Institute of Technology Hyderabad, Kandi, Sangareddy 502285, Telangana, India
}

Supporting Information

ABSTRACT: The hydrodeoxygenation (HDO) of vegetable oil and fatty acid is extremely important for the sustainable production of dieselrange hydrocarbons. The present work depicts the role of $\mathrm{Ni} / \mathrm{Mo}$ (mole) in the performance of alumina-supported NiMo catalysts for the HDO of stearic acid. Both $\mathrm{Ni}$ and $\mathrm{NiMo}$ alloy coexist in the NiMo catalysts depending on the $\mathrm{Ni}$ and Mo content. With increasing $\mathrm{Ni} / \mathrm{Mo}$ (mole), the NiMo alloy content in the catalyst increases with the simultaneous decrease in the Ni content. The activity of NiMo catalysts thus enhances with increasing $\mathrm{Ni} / \mathrm{Mo}$ (mole). The reaction follows a decarbonylation route over $\mathrm{Ni}$ sites and a $\mathrm{HDO}$ route over NiMo alloy species. $\mathrm{C}_{17}$ and $\mathrm{C}_{18}$ alkanes are thus observed as the dominating hydrocarbon product

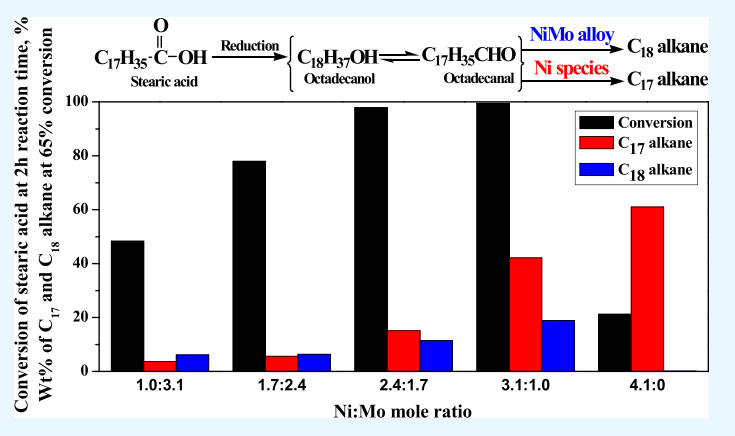
over $\mathrm{Ni}$ and NiMo alloy-rich catalysts, respectively. The activity of the NiMo catalyst further enhances with increasing reaction temperature and metal $(\mathrm{Ni}+\mathrm{Mo})$ loading. The selectivity to alkanes was, however, not affected by metal loading. A suitable kinetic model was further established based on the reaction mechanism to relate the kinetic data.

\section{INTRODUCTION}

In the past few decades, considerable attention has been devoted to renewable resources to reduce dependency on finite fossil fuels. These efforts are intended to achieve energy security of the world in a sustainable manner. The renewable resources also play an important role in preserving a healthy environment. Currently, transportation fuels consume about $28 \%$ of the world's energy. ${ }^{1}$ A significant effort has thus been made to produce transportation fuels from renewable carbonneutral resources such as biomass. The use of biomass for biofuels will further boost the growth of agriculture-based industries and improvement in the rural economy. Several national-level policies are thus framed to promote biofuels. For example, India targeted about $20 \%$ blending of biofuels (bioethanol and biodiesel) with transportation fuels. ${ }^{2}$ Following the 2 nd commitment of the Kyoto protocol, the countries are now targeting $18 \%$ reduction of greenhouse gas emission between 2013 and $2020 .^{3}$

Three different classes of biomass are used in the biorefinery: triglycerides, sugar and starch, and lignocellulosic. Among these, the triglyceride is simple in structure with low functionality and oxygen content and a long-chain linear hydrocarbon backbone. The triglycerides are mainly composed of $\mathrm{C}_{16}$ and $\mathrm{C}_{18}$ fatty acids. ${ }^{4}$ Hence, it is an ideal feedstock for the diesel-range transportation fuel. Transesterification is one such well-accepted technology for the production of transportation fuels from triglycerides known as biodiesel. A significant advancement has thus been made in the production of biodiesel from triglycerides. ${ }^{5}$ The biodiesel has, however, the maximum limit of $20 \%$ blending with diesel for application in unmodified combustion engines because of its unfavorable cold flow properties. Furthermore, it delivers lower fuel mileage because of the presence of oxygen in the structure. $^{5}$ The removal of oxygen from triglycerides is thus vital in producing diesel-range hydrocarbons (green diesel) for direct use in a diesel engine. The pyrolysis and catalytic cracking are two potential processes in the production of green diesel from triglycerides. ${ }^{6}$ However, these processes provide a low yield of green diesel and high yield of gaseous products.

Hydrodeoxygenation (HDO) is another process for the manufacturing of green diesel from triglycerides in high yield. This process is analogous to the hydroprocessing technology used in the petroleum refinery and carried out over supported metal catalysts in the presence of hydrogen. ${ }^{7}$ The likelihood of the retrofitting with petroleum refinery production facilities is an added advantage of this process. ${ }^{8}$ The triglycerides can be converted to green diesel through two alternative approaches: direct HDO of triglycerides and HDO of fatty acids derived from triglycerides. In the latter approach, the triglycerides are generally (catalytically or noncatalytically) hydrolyzed to corresponding fatty acids. ${ }^{9}$ Following the latter approach, the present work is focused on the HDO of stearic acid $\left(\mathrm{C}_{17}-\right.$ $\mathrm{COOH}$ ) as a model fatty acid.

Received: December 21, 2018

Accepted: January 24, 2019

Published: February 7, 2019 
Table 1. Physicochemical Properties of the Catalysts ${ }^{a}$

\begin{tabular}{|c|c|c|c|c|c|c|c|}
\hline \multirow[b]{2}{*}{ catalyst } & \multicolumn{2}{|c|}{ surface area, $\mathrm{m}^{2} / \mathrm{g}$} & \multicolumn{2}{|c|}{ pore volume, $\mathrm{cm}^{3} / \mathrm{g}$} & \multirow{2}{*}{$\frac{\text { crystallite size, nm }}{\text { red }^{b}}$} & \multirow[b]{2}{*}{$\mathrm{MD}$} & \multirow[b]{2}{*}{$\mathrm{Sm}$} \\
\hline & $\mathrm{cal}$ & red & $\mathrm{Cal}$ & red & & & \\
\hline$\gamma-\mathrm{Al}_{2} \mathrm{O}_{3}$ & 243 & & 0.86 & & & & \\
\hline 4.1MoAl & 57 & 90 & 0.36 & 0.49 & & 0.07 & 0.30 \\
\hline 1.0Ni3.1MoAl & 103 & 86 & 0.56 & 0.57 & $31.3^{c}$ & 0.05 & 0.36 \\
\hline $1.7 \mathrm{Ni} 2.4 \mathrm{MoAl}$ & 109 & 94 & 0.54 & 0.53 & $39.4^{c}$ & 0.11 & 0.55 \\
\hline $2.4 \mathrm{Ni} 1.7 \mathrm{MoAl}$ & 123 & 118 & 0.56 & 0.55 & $41.3^{c}$ & 0.22 & 1.45 \\
\hline 3.1Ni1.0MoAl & 146 & 123 & 0.58 & 0.56 & $44.9^{c}$ & 0.50 & 3.31 \\
\hline $4.1 \mathrm{NiAl}$ & 169 & 135 & 0.57 & 0.51 & $44.8^{d}$ & 1.01 & 6.70 \\
\hline $1.8 \mathrm{Nil} .2 \mathrm{MoAl}$ & 126 & 122 & 0.52 & 0.54 & & 0.30 & 1.8 \\
\hline $1.2 \mathrm{Ni} 0.8 \mathrm{MoAl}$ & 132 & 127 & 0.56 & 0.61 & & 0.35 & 1.94 \\
\hline $0.9 \mathrm{Ni} 0.6 \mathrm{MoAl}$ & 137 & 131 & 0.54 & 0.57 & & 0.36 & 2.01 \\
\hline
\end{tabular}

${ }^{a} \mathrm{cal}=$ calcined; red $=$ reduced; $\mathrm{MD}=$ metal dispersion, $\% ; \mathrm{Sm}=$ metallic surface area, $\mathrm{m}^{2} / \mathrm{g}$ metal. ${ }^{b}$ Calculated using the Debye $-\mathrm{Scherrer}$ equation . ${ }^{c} \mathrm{NiMo}$ alloy. ${ }^{d} \mathrm{Ni}$.

A vast number of works have been reported in the past on the HDO of numerous model fatty acids such as decanoic, dodecanoic, lauric, palmitic, stearic, oleic, and linoleic. ${ }^{4,10-18}$ Similar to hydrotreatment, the sulfided form of supported metal catalysts has also been employed for the HDO of vegetable oil and fatty acids. ${ }^{13,19-21}$ These catalysts are, however, accompanied with sulfur contamination of green diesel and deactivation because of sulfur leaching. ${ }^{22}$ The sulfurfree-supported metal catalysts have thus attracted huge attention for this process. HDO has also been studied over noble metal (Pt, Pd, Ru, etc.) catalysts. ${ }^{23-28}$ For example, Pd/ $\mathrm{C}$ demonstrated high catalytic activity for the HDO of fatty acids. $^{24}$ These catalysts are, however, highly expensive. On the other hand, the transition metals ( $\mathrm{Ni}, \mathrm{Co}, \mathrm{NiMo}$, and $\mathrm{CoMo}$ ) are inexpensive with high catalytic activity and stability. Hence, these catalysts have been reported extensively for this reaction by various research groups. ${ }^{4,29-34}$ For example, $\mathrm{HDO}$ of $\mathrm{C}_{17}-$ $\mathrm{COOH}$ was studied over $\mathrm{SiO}_{2}, \gamma-\mathrm{Al}_{2} \mathrm{O}_{3}$, and HZSM-5supported $\mathrm{Ni}$ catalyst. ${ }^{4}$ The $\mathrm{C}_{17}$ alkane was reported as the main product over $\mathrm{Ni} / \gamma-\mathrm{Al}_{2} \mathrm{O}_{3}$. The $\mathrm{HY}, \gamma-\mathrm{Al}_{2} \mathrm{O}_{3}$, and $\mathrm{SiO}_{2}-$ supported $\mathrm{Ni}$ catalysts were also reported for the $\mathrm{HDO}$ of $\mathrm{C}_{17}-\mathrm{COOH}$ and conversion of $\mathrm{C}_{17}-\mathrm{COOH}$ of 94,43 , and $46 \%$ was achieved at $90 \mathrm{~min}$ of reaction time, respectively. ${ }^{35}$

The deoxygenation pathway depends on the nature of active sites present in the catalyst. The decarbonylation pathway is dominant over $\mathrm{Ni}$ catalysts. This route produces alkane with one carbon less than the fatty acid. ${ }^{4,17,35}$ The reaction, however, follows the HDO pathway over bimetallic catalysts (NiMo and CoMo). ${ }^{36}$ The nonsulfided $\mathrm{NiMo} / \gamma-\mathrm{Al}_{2} \mathrm{O}_{3}$ showed the higher yield of green diesel from sunflower oil and waste cooking oil compared to the sulfided catalyst. ${ }^{37}$ The nonsulfided $\mathrm{CoMo} / \gamma-\mathrm{Al}_{2} \mathrm{O}_{3}$ catalyst showed high catalytic activity with $100 \%$ hydrocarbon product containing $74 \%$ paraffin from sunflower oil.

The atomic composition of $\mathrm{Ni}$ and $\mathrm{Mo}$ in the supported NiMo catalyst is a governing factor to obtain the catalytically active NiMo alloy species. ${ }^{33,37-39}$ Wang et al. studied the effect of $\mathrm{Ni} / \mathrm{Mo}$ (mole) and metal loading on structure, reducibility, and metal dispersion. ${ }^{40}$ The detailed study on Ni/Mo (mole) is, however, scarcely available in the literature. The present work is thus focused on the preparation of alumina-supported NiMo catalysts with different $\mathrm{Ni} / \mathrm{Mo}$ (mole). These catalysts were further characterized by several techniques to understand the formation of various active surface species. The HDO activity and product selectivity over these catalysts were then qualitatively correlated with the structural information. For optimum $\mathrm{Ni} / \mathrm{Mo}$ (mole), the study was then extended to different metal $(\mathrm{Ni}+\mathrm{Mo})$ loadings to obtain the optimum metal loading. The kinetics play an important role in the reactor design. ${ }^{4,25,40-42}$ The kinetics of HDO over monometallic catalysts were reported by various research groups in the past. ${ }^{4,24,41,43,44}$ The kinetic model for the HDO of fatty acids over the bimetallic catalyst is, however, scarcely available in the literature. Hence, a suitable kinetic model was developed in this work for the $\mathrm{HDO}$ of $\mathrm{C}_{17}-\mathrm{COOH}$ over the aluminasupported NiMo catalyst.

\section{RESULTS AND DISCUSSION}

2.1. Catalyst Characterization. 2.1.1. BET Surface Area. Table 1 shows Brunauer-Emmett-Teller (BET) surface area and pore volume of $\gamma-\mathrm{Al}_{2} \mathrm{O}_{3}$ and NiMo catalysts. The surface area of $\gamma-\mathrm{Al}_{2} \mathrm{O}_{3}$ was $243 \mathrm{~m}^{2} / \mathrm{g}$ with a pore volume of $0.86 \mathrm{~cm}^{3} /$ g. Both calcined and reduced NiMo catalysts showed lesser surface area and pore volume compared to $\gamma-\mathrm{Al}_{2} \mathrm{O}_{3}$. The surface area of both calcined and reduced NiMo catalysts was further decreased with increasing Mo content and metal (Ni + Mo) loading. The drop in surface area with increasing Mo content and metal loading might be due to the greater coverage of the alumina surface or pore blockage by the high atomic weight Mo (and/or $\mathrm{Ni}$ ) metal/metal oxide species. Excepting $4.1 \mathrm{MoAl}$, the surface area of the reduced NiMo catalyst was, however, lower than that of the corresponding calcined catalyst. It might be due to the additional sintering of metals during reduction. In the case of $4.1 \mathrm{MoAl}$, the $\mathrm{MoO}_{3}$ clusters were formed during calcination. During reduction, these $\mathrm{MoO}_{3}$ clusters were reduced to dispersed $\mathrm{Mo}$ or molybdenum oxide, resulting in a slight increase in the surface area. $^{40}$

2.1.2. Pulse Chemisorption. The metal dispersion and metallic surface area of NiMo catalysts were declined with increasing Mo content and metal $(\mathrm{Ni}+\mathrm{Mo})$ loading in the catalyst (Table 1). It might be due to the enrichment of $\mathrm{MoO}_{3}$ clusters with increasing Mo content, leading to the formation of $\mathrm{Al}_{2}\left(\mathrm{MoO}_{4}\right)_{3}$. The Raman spectra further confirmed the presence of $\mathrm{Al}_{2}\left(\mathrm{MoO}_{4}\right)_{3}$ in the calcined NiMo catalyst (Figure 1). Giordano et al. also reported augmentation of the $\mathrm{MoO}_{3}$ cluster with increasing $\mathrm{MoO}_{3}$ content on alumina. ${ }^{45}$ The decrease in metal dispersion and metallic surface area with increasing metal loading might be due to agglomeration of metals at higher metal loading.

2.1.3. Raman Spectroscopy. Figure 1 shows Raman spectra of calcined NiMo catalysts under ambient conditions. Raman 


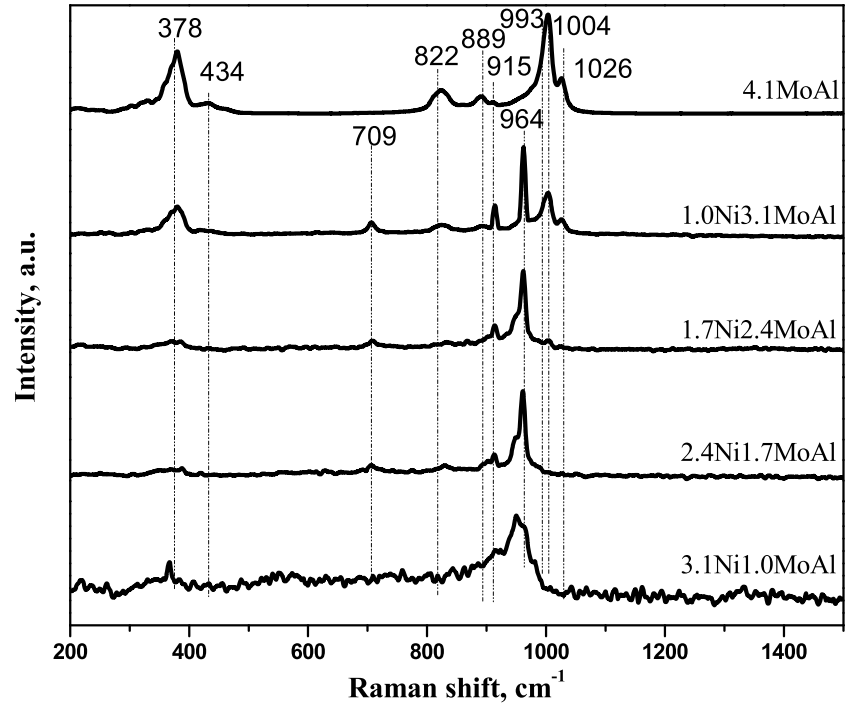

Figure 1. Raman spectra of calcined NiMo and Mo catalysts.

bands at $\sim 993,1004$, and $1026 \mathrm{~cm}^{-1}$ were characteristics of $\mathrm{Mo}=\mathrm{O}$ bond vibration of three $\mathrm{MoO}_{4}$ units present in $\mathrm{Al}_{2}\left(\mathrm{MoO}_{4}\right)_{3}$. Tian et al. also observed similar bands in Raman spectra of bulk $\mathrm{Al}_{2}\left(\mathrm{MoO}_{4}\right)_{3}{ }^{46}$ and reference therein. The Raman bands at 822,889 , and $915 \mathrm{~cm}^{-1}$ were attributed to the asymmetric stretching of three $\mathrm{MoO}_{4}$ units present in $\mathrm{Al}_{2}\left(\mathrm{MoO}_{4}\right)_{3}^{46}$ and reference therein. These bands became intense with increasing Mo content. These results implied the enrichment of $\mathrm{Al}_{2}\left(\mathrm{MoO}_{4}\right)_{3}$ with increasing Mo content in the NiMo catalyst. The bands appeared at 434 and $378 \mathrm{~cm}^{-1}$ were due to asymmetric and symmetric bending modes of isolated $\mathrm{MoO}_{4}$ units. Raman bands at 709 and $964 \mathrm{~cm}^{-1}$ were attributed to the $\mathrm{NiMoO}_{4}$ species. ${ }^{47}$ These bands were observed in all calcined NiMo catalysts. Moreover, these bands became sharp and intense with increasing Mo content in the NiMo catalyst. The strong $\mathrm{MoO}_{4}$ bands in $1.0 \mathrm{Ni} 3.1 \mathrm{MoAl}$ suggested a high concentration of $\mathrm{Al}_{2}\left(\mathrm{MoO}_{4}\right)_{3}$. Liu et al. also reported similar observation. ${ }^{48}$ For the NiMo catalyst, the Raman bands corresponding to bridging $\mathrm{Mo}-\mathrm{O}-\mathrm{Mo}$ bonds were absent in the Raman shift region of 200-300 and 500$800 \mathrm{~cm}^{-1}$. These results further confirmed the presence of different isolated $\mathrm{MoO}_{4}$ units of $\mathrm{Al}_{2}\left(\mathrm{MoO}_{4}\right){ }^{46}$

2.1.4. UV-Vis-NIR Spectra. Figure $\mathrm{S} 2$ shows UV-vis spectra of calcined NiMo catalysts. The UV-vis band appeared at $263 \mathrm{~nm}$ was assigned to the $\mathrm{O}^{2-}$ to $\mathrm{Mo}^{6+}$ ligand to metal charge transfer of the isolated $\mathrm{MoO}_{4}$ units present in $\mathrm{Al}_{2}\left(\mathrm{MoO}_{4}\right)_{3}{ }^{46}$ The UV-vis absorption band at $263 \mathrm{~nm}$ in 4.1MoAl is relatively strong compared to that in the NiMo catalysts. This band became intense with increasing Mo content in NiMo catalysts. This result shows that the formation of $\mathrm{Al}_{2}\left(\mathrm{MoO}_{4}\right)_{3}$ was increased with increasing $\mathrm{Mo}$ content in the NiMo catalyst. The UV-vis band appeared at $621 \mathrm{~nm}$ was attributed to $\mathrm{NiAl}_{2} \mathrm{O}_{4}{ }^{43}$ This band was intense in $3.1 \mathrm{Ni1} .0 \mathrm{MoAl}$. This result indicated that the formation of $\mathrm{NiAl}_{2} \mathrm{O}_{4}$ was increased with an increase in the $\mathrm{Ni} / \mathrm{Mo}$ (mole).

2.1.5. Powder XRD. Figure 2A shows powder X-ray diffraction (XRD) pattern of calcined NiMo catalysts. The characteristic diffraction peaks at $2 \theta$ of $45^{\circ}\left(\begin{array}{lll}4 & 0 & 0\end{array}\right)$ and $65.5^{\circ}$ (4 4 0) corresponded to the $\mathrm{NiAl}_{2} \mathrm{O}_{4}$ species [PDF\#781601]. The previous studies also reported $\mathrm{NiAl}_{2} \mathrm{O}_{4}$ in the $\mathrm{Ni}$ /alumina catalyst. ${ }^{49,50} \mathrm{NiAl}_{2} \mathrm{O}_{4}$ is, however, very difficult to distinguish

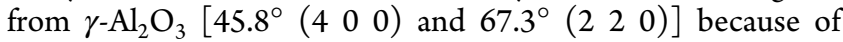
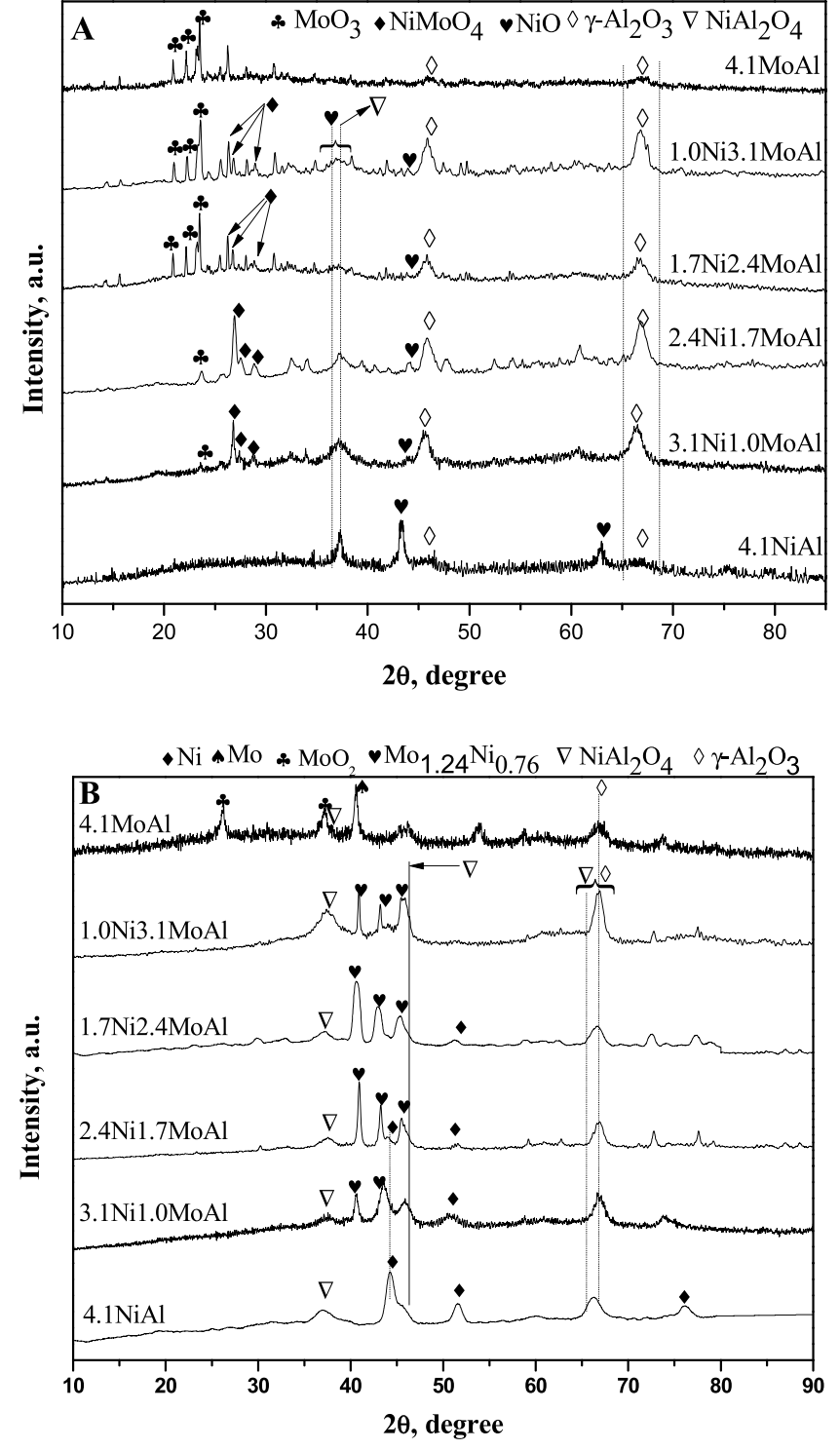

Figure 2. Powder XRD pattern of (A) calcined and (B) reduced $\mathrm{NiMo}$ catalysts with different $\mathrm{Ni} / \mathrm{Mo}$ mole ratios.

overlapping diffraction peaks. The broad peaks at $2 \theta$ of $45^{\circ}-$ $47^{\circ}$ and $65^{\circ}-67^{\circ}$ were thus considered as the combined diffraction peak of $\mathrm{NiAl}_{2} \mathrm{O}_{4}$ and $\gamma-\mathrm{Al}_{2} \mathrm{O}_{3}$. The broad peaks appeared at $2 \theta$ of $37^{\circ}-38^{\circ}$ were considered as combined diffraction peaks of $\mathrm{NiO}$ and $\mathrm{NiAl}_{2} \mathrm{O}_{4}$. The calcined $\mathrm{NiMo}$ catalysts revealed characteristic $\mathrm{NiO}$ peaks at $2 \theta$ of $37.16^{\circ}(11$ 1), $43.54^{\circ}$ (2 00 ), and $62.98^{\circ}$ (2 20 ) [PDF\#750197]. . $^{4,51}$ The intensity of $\mathrm{NiO}$ peaks at $2 \theta$ of $37.16^{\circ}$ and $43.54^{\circ}$ was increased with increasing $\mathrm{Ni} / \mathrm{Mo}$ (mole) and practically disappeared in $1.7 \mathrm{Ni} 2.4 \mathrm{MoAl}$ and $1.0 \mathrm{Ni} 3.1 \mathrm{MoAl}$. The $\mathrm{MoO}_{3}$ diffraction peaks appeared at $2 \theta$ of $20.81^{\circ}\left(\begin{array}{lll}1 & 1 & 1\end{array}\right), 23.15^{\circ}\left(\begin{array}{ll}0 & 0\end{array}\right.$ 2), $23.30^{\circ}\left(\begin{array}{lll}0 & 2 & 0\end{array}\right), 23.49^{\circ}\left(\begin{array}{lll}2 & 0 & 0\end{array}\right)$, and $26.3^{\circ}\left(\begin{array}{lll}2 & 1 & 0\end{array}\right)$ [PDF\#800347]. ${ }^{51-53}$ These peaks became intense with increasing Mo content in the catalyst. The calcined NiMo catalysts additionally showed $\mathrm{NiMoO}_{4}$ species diffraction peaks at $2 \theta$ of $24.28^{\circ}\left(\begin{array}{lll}0 & 1 & 1\end{array}\right), 25.46^{\circ}\left(\begin{array}{lll}1 & 1 & 0\end{array}\right)$, and $31.15^{\circ}\left(\begin{array}{lll}1 & 1 & 1\end{array}\right)$ [PDF\#860362]. The $\mathrm{NiMoO}_{4}$ species was also reported in previous studies. ${ }^{54,55}$ The $\mathrm{NiMoO}_{4}$ species peaks were sharp and intense for $2.4 \mathrm{Ni} 1.7 \mathrm{MoAl}$ and weak for both higher and lower Mo content in the catalyst. The intensity of the 
characteristic $\mathrm{NiO}$ and $\mathrm{NiMoO}_{4}$ species peaks was increased with increasing metal loading as shown in Figure S1. The characteristic $\mathrm{NiO}$ peak at $2 \theta$ of $43.58^{\circ}\left(\begin{array}{lll}2 & 0 & 0\end{array}\right)$ was absent in $0.9 \mathrm{Ni0} .6 \mathrm{MoAl}$ (Figure S1). It might be due to the existence of dispersed $\mathrm{NiO}$ below the detection limit of powder XRD or $\mathrm{NiO}$ was completely consumed for the formation of $\mathrm{NiMoO}_{4}$ species.

Figure 2B shows the powder XRD pattern of reduced NiMo catalysts. The reduced $4.1 \mathrm{NiAl}$ showed three characteristic $\mathrm{Ni}$ peaks at $2 \theta$ of $44.48^{\circ}\left(\begin{array}{lll}1 & 1 & 1\end{array}\right), 51.83^{\circ}\left(\begin{array}{lll}2 & 0 & 0\end{array}\right)$, and $76.352^{\circ}(22$ $0)$ [PDF\#701849]. ${ }^{4,51}$ The intensity of Ni peaks was decreased gradually with decreasing $\mathrm{Ni} / \mathrm{Mo}$ (mole) and disappeared in 1.0Ni3.1MoAl. It might be due to complete consumption of $\mathrm{Ni}$ in the formation of $\mathrm{NiMoO}_{4}$ or the crystallite size of $\mathrm{Ni}$ was below the detection limit of powder XRD. Wang et al. also reported an increase in the intensity of the $\mathrm{NiMoO}_{4}$ diffraction peak with decreasing $\mathrm{Ni} / \mathrm{Mo}$ (mole). ${ }^{40}$ The reduced $4.1 \mathrm{MoAl}$ showed Mo peaks at $2 \theta$ of $40.47^{\circ}\left(\begin{array}{lll}1 & 1 & 0\end{array}\right)$ and molybdenum dioxide $\left(\mathrm{MoO}_{2}\right)$ at $2 \theta$ of $26.26^{\circ}\left(\begin{array}{lll}1 & 1 & 1\end{array}\right)$ and $37.21^{\circ}\left(\begin{array}{lll}2 & 0 & 0\end{array}\right)$. The reduced $3.1 \mathrm{Ni1} .0 \mathrm{MoAl}$ displayed diffraction peaks of the NiMo alloy $\left(\mathrm{Mo}_{1.24} \mathrm{Ni}_{0.76}\right)$ at $2 \theta$ of $40.63^{\circ}\left(\begin{array}{lll}4 & 0 & 1\end{array}\right), 43.73^{\circ}$ (3 1 $3)$, and $45.58^{\circ}\left(\begin{array}{lll}2 & 0 & 4\end{array}\right)$ [PDF\#471129]. These peaks were intensified with the increasing Mo content up to $1.7 \mathrm{Ni} 2.4 \mathrm{MoAl}$ and decreased slightly with the further increase in Mo content (1.0Ni3.1MoAl). The intensity of NiMo alloy diffraction peaks was increased with increasing metal loading as shown in Figure S1. Mo and $\mathrm{MoO}_{2}$ were, however, not observed in reduced NiMo catalysts. This result implies that the presence of $\mathrm{Ni}$ enhances the reducibility of $\mathrm{MoO}_{2}$. The absence of Mo diffraction peaks might be due to complete consumption of Mo in the formation of the NiMo alloy or the quantity of Mo was below the detection limit of powder $\mathrm{XRD}$. $\mathrm{NiAl}_{2} \mathrm{O}_{4}$ was observed at $2 \theta$ of $37.16^{\circ}$. The intensity of this peak was weak for all the catalysts. The peak associated with $\mathrm{Ni}$ was also observed in $1.8 \mathrm{Ni} 1.2 \mathrm{MoAl}$ and $2.4 \mathrm{Ni1} .7 \mathrm{MoAl}$ (Figure S1).

2.1.6. Temperature-Programmed Reduction (TPR) Profile. Figure 3 shows the temperature-programmed reduction (TPR) profile of calcined NiMo catalysts. $4.1 \mathrm{NiAl}$ exhibited three characteristic reduction peaks at $T_{\max }$ of 657,703 , and $1014 \mathrm{~K}$. The first peak at $\sim 657 \mathrm{~K}$ was characteristics of the reduction of bulk $\mathrm{NiO}$ with a weak interaction with support. The bulk $\mathrm{NiO}$ reduction peak was, however, absent in all NiMo catalysts excepting 3.1Ni1.0MoAl. The bulk $\mathrm{NiO}$ reduction peak in 3.1 Nil.0MoAl was observed at a slightly lower temperature than the corresponding peak in $4.1 \mathrm{NiAl}$. The second reduction peak at $\sim 703 \mathrm{~K}$ was due to the reduction of dispersed $\mathrm{NiO}$ with a strong interaction with the support. The third hightemperature reduction peak at $\sim 1014 \mathrm{~K}$ was attributed to the reduction of $\mathrm{NiAl}_{2} \mathrm{O}_{4}$. $\mathrm{NiAl}_{2} \mathrm{O}_{4}$ was also observed in the powder XRD pattern of the calcined $\mathrm{Ni}$ catalyst (Figure 2). The reducible $\mathrm{NiAl}_{2} \mathrm{O}_{4}$ was observed in the calcined NiMo catalyst with high $\mathrm{Ni}$ content only (3.1Ni1.0MoAl). $\mathrm{NiAl}_{2} \mathrm{O}_{4}$ was also reported by $\mathrm{Li}$ et al. at $T_{\max }$ of $1064 \mathrm{~K}$ and Kumar et al. at $T_{\max }$ of $950 \mathrm{~K}$.,56

4.1MoAl displayed three characteristic reduction peaks at $T_{\max }$ of 694,796 , and $\sim 989 \mathrm{~K}$. The first reduction peak was associated with the partial reduction of $\mathrm{MoO}_{3}$ to $\mathrm{MoO}_{2}$. The second reduction peak was due to the reduction of $\mathrm{MoO}_{2}$ to Mo. The reduction peak at $\sim 989 \mathrm{~K}$ might be due to the reduction of $\mathrm{Al}_{2}\left(\mathrm{MoO}_{4}\right)_{3} .{ }^{57}$ The presence of $\mathrm{Al}_{2}\left(\mathrm{MoO}_{4}\right)_{3}$ in 4.1MoAl and NiMo catalysts with high Mo content was also confirmed by Raman spectroscopy as discussed in the previous section.
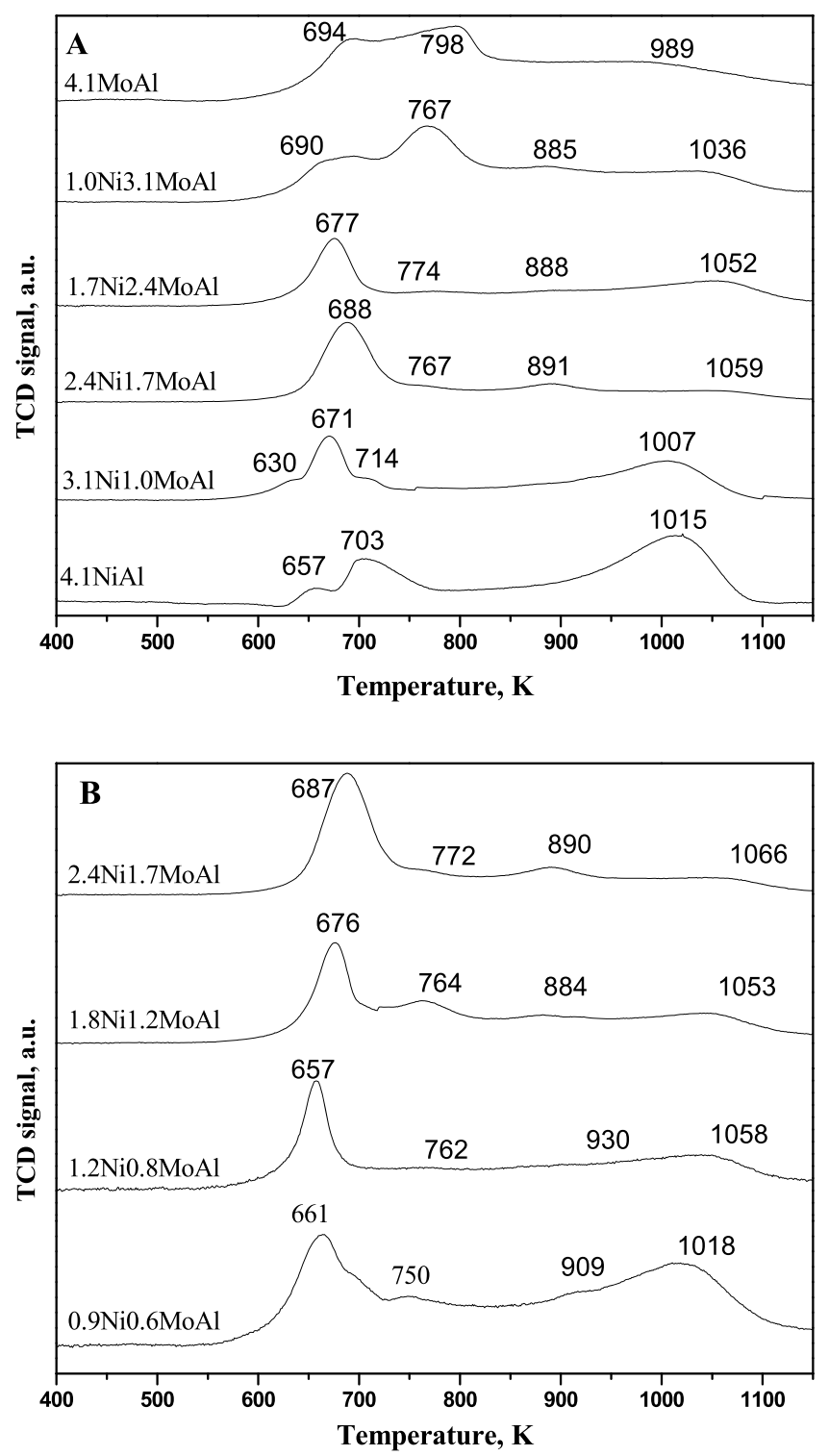

Figure 3. TPR profile of NiMo catalysts with different (A) Ni/Mo mole ratio and (B) metals loading.

The calcined NiMo catalysts exhibited four distinct reduction peaks at $T_{\max }$ of $661-695,750-774,886-891$, and 989-1058 $\mathrm{K}$ depending on $\mathrm{Ni} / \mathrm{Mo}$ (mole) and metal loading. The dispersed $\mathrm{NiO}, \mathrm{MoO}_{3}$, and $\mathrm{NiMoO}_{4}$ are reduced over a narrow temperature range (Figure $3 \mathrm{~A}$ ), and hence, their reduction peaks are often indistinguishable. The first reduction peak at $661-695 \mathrm{~K}$ was thus considered as the simultaneous reduction of dispersed $\mathrm{NiO}, \mathrm{MoO}_{3}$, and $\mathrm{NiMoO}_{4}$. For the NiMo catalyst with high $\mathrm{Ni}$ content such as $3.1 \mathrm{Ni1} .0 \mathrm{MoAl}$, this peak was weak and broad. On the other hand, the $\mathrm{MoO}_{3}$ diffraction peak was weak in calcined $3.1 \mathrm{Nil} .0 \mathrm{MoAl}$ (Figure 2). Therefore, this reduction peak might be attributed to the simultaneous reduction of dispersed $\mathrm{NiO}$ and $\mathrm{NiMoO}_{4}$ in 3.1Ni1.0MoAl. For the NiMo catalyst with moderate $\mathrm{Ni}$ and Mo content such as $2.4 \mathrm{Ni} 1.7 \mathrm{MoAl}$ and $1.7 \mathrm{Ni} 2.4 \mathrm{MoAl}$, this reduction peak was sharp and intense. The powder XRD pattern of these catalysts revealed the weak diffraction peaks of $\mathrm{MoO}_{3}$ and $\mathrm{NiO}$. This reduction peak for these catalysts was thus due to the reduction of $\mathrm{NiMoO}_{4}$ predominately. The $\mathrm{NiMoO}_{4}$ diffraction peak also became sharp and intense with 
decreasing $\mathrm{Ni} / \mathrm{Mo}$ (mole) with the simultaneous decline in intensity of the $\mathrm{NiO}$ peak (Figure 2). A similar observation was also reported by Wang et al.. ${ }^{40}$ This reduction peak was also intense and sharp in the NiMo catalyst with different metal loading (Figure $3 \mathrm{~B}$ ). The $T_{\max }$ of this peak was, however, increased with increasing metal loading. This reduction peak was, however, broad with a shoulder in the NiMo catalyst with high Mo content such as $1.0 \mathrm{Ni} 3.1 \mathrm{MoAl}$ and attributed to the reduction of both $\mathrm{MoO}_{3}$ and $\mathrm{NiMoO}_{4}$.

The second peak appeared in the NiMo catalyst at 750-774 $\mathrm{K}$ was due to the reduction of $\mathrm{MoO}_{2}$ to Mo. This peak was practically absent in $3.1 \mathrm{Ni} 1.0 \mathrm{MoAl}$ and quite weak for all NiMo catalysts excepting $1.0 \mathrm{Ni} 3.1 \mathrm{MoAl}$. The peak appeared at 886-891 K was attributed to the reduction of intermediate reducible phases. The reduction temperature of $\mathrm{NiAl}_{2} \mathrm{O}_{4}$ and $\mathrm{Al}_{2}\left(\mathrm{MoO}_{4}\right)_{3}$ is quite close. The broad peak appeared in the NiMo catalyst at 989-1058 $\mathrm{K}$ was thus considered as the simultaneous reduction of $\mathrm{NiAl}_{2} \mathrm{O}_{4}$ and $\mathrm{Al}_{2}\left(\mathrm{MoO}_{4}\right)_{3}$. This reduction peak was, however, quite significant in the NiMo catalyst with high $\mathrm{Ni}$ content such as $3.1 \mathrm{Ni} 1.0 \mathrm{MoAl}$ and considered as the reduction of $\mathrm{NiAl}_{2} \mathrm{O}_{4}$ mainly. The $T_{\max }$ of this reduction peak was further decreased slightly with increasing Mo content in the NiMo catalyst.

2.2. Reaction Pathway. In general, the fatty acids are reduced to fatty alcohol by hydrogen in presence of metallic catalysts. A significant quantity of octadecanol $\left(\mathrm{C}_{18}-\mathrm{OH}\right)$ was also observed during this study. The deoxygenation of $\mathrm{C}_{18}-$ $\mathrm{OH}$ then follows two different reaction pathways (RPs) depending on the nature of the active centers present in the catalysts: (i) HDO, where oxygen is eliminated as water (RP-I) and (ii) decarbonylation, where oxygen is removed as $\mathrm{CO}$ (RP-II) (Scheme 1). ${ }^{13,21,38,58}$ Following RP-I, $\mathrm{C}_{18}-\mathrm{OH}$

Scheme 1. Reaction Pathway for the HDO of Stearic Acid over the Alumina-Supported NiMo Catalyst

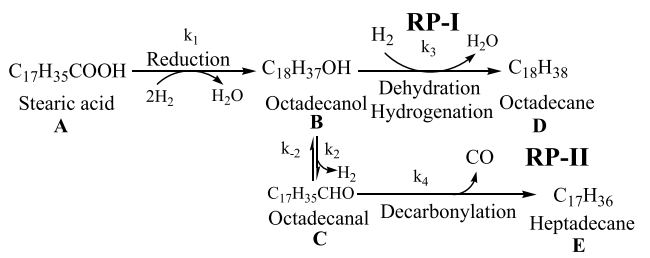

undergoes dehydration, followed by hydrogenation to form a $\mathrm{C}_{18}$ alkane. RP-I is the dominant route over the NiMo catalyst. On the basis of the characterization of the NiMo catalysts, it is speculated that this route follows over NiMo alloy species. In RP-II, $\mathrm{C}_{18}-\mathrm{OH}$ undergoes dehydrogenation to form octadecanal $\left(\mathrm{C}_{17}-\mathrm{CHO}\right) . \mathrm{C}_{17}-\mathrm{CHO}$ then undergoes decarbonylation to form a $\mathrm{C}_{17}$ alkane. A small quantity of $\mathrm{C}_{17}-\mathrm{CHO}$ was detected during the reaction. This route follows over the metallic sites and dominant over the Ni catalyst.

2.3. HDO of Stearic Acid. 2.3.1. Effect of the Ni/Mo Mole Ratio. For a fixed metal ( $\mathrm{Ni}+\mathrm{Mo})$ loading of $4.1 \mathrm{mmol} / \mathrm{g}, \mathrm{Ni} /$ Mo (mole) was varied to understand its role in the catalytic performance. The conversion of $\mathrm{C}_{17}-\mathrm{COOH}$ was about $65 \%$ over $4.1 \mathrm{NiAl}$ at $360 \mathrm{~min}$ of reaction time (Figure $4 \mathrm{~A}$ ). The conversion of $\mathrm{C}_{17}-\mathrm{COOH}$ was improved with increasing $\mathrm{Ni}$ / Mo (mole). Almost complete conversion of $\mathrm{C}_{17}-\mathrm{COOH}$ was achieved over $2.4 \mathrm{Ni} 1.7 \mathrm{MoAl}$ and $3.1 \mathrm{Ni} 1.0 \mathrm{MoAl}$ at $240 \mathrm{~min}$ of reaction time. The initial reaction rate over different catalysts was as follows: $4.5 \times 10^{-6}, 8.2 \times 10^{-6}, 1.5 \times 10^{-5}, 2.6 \times 10^{-5}$, and $3.1 \times 10^{-5} \mathrm{kmol} / \mathrm{m}^{3} \mathrm{~s}$ for $4.1 \mathrm{NiAl}, 1.0 \mathrm{Ni} 3.1 \mathrm{MoAl}$,
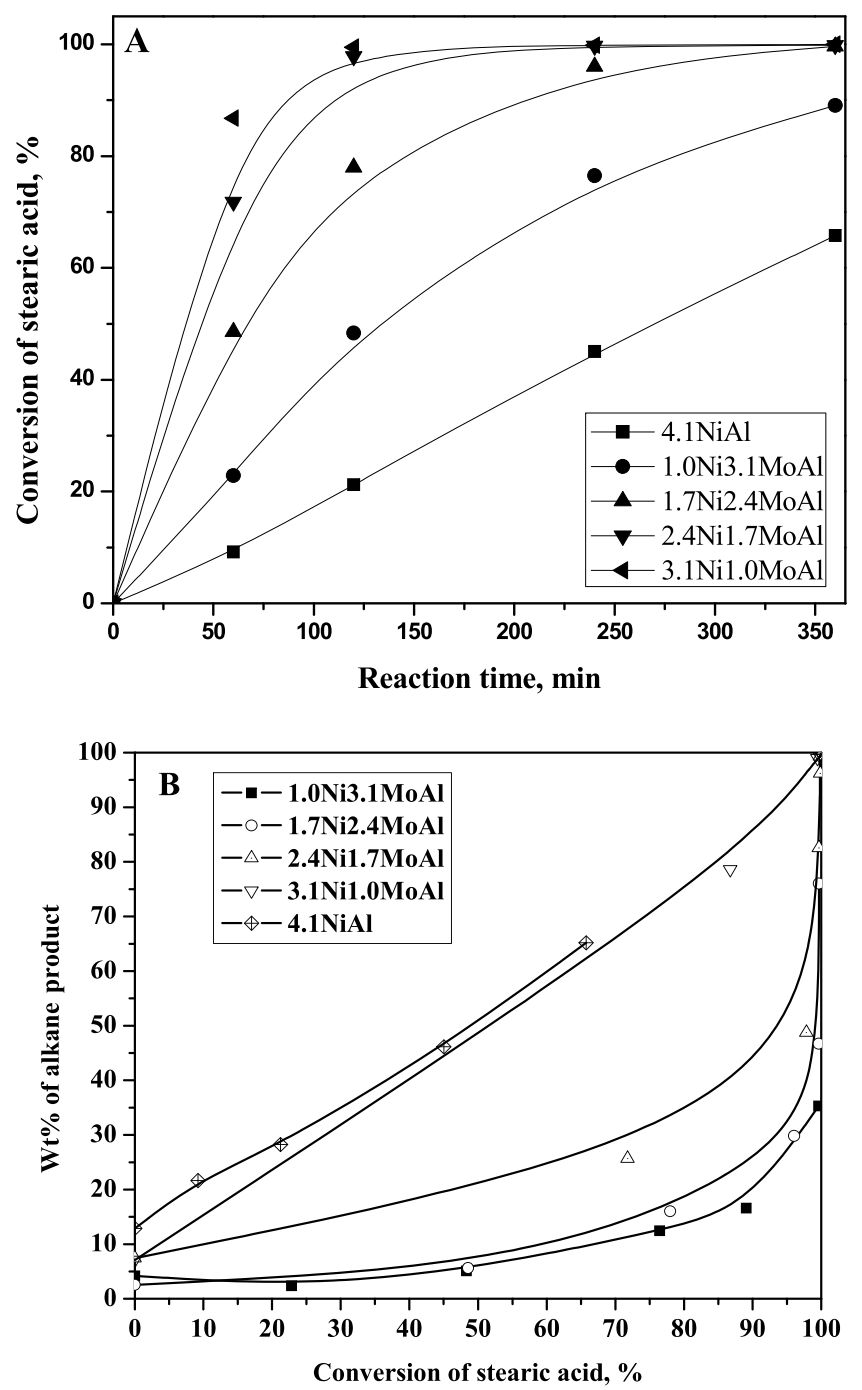

Figure 4. Effect of Ni/Mo mole ratio on (A) conversion of stearic acid and (B) wt \% of alkane product at various conversions of stearic acid. Reaction conditions: concentration of stearic acid $=0.18 \mathrm{kmol} /$ $\mathrm{m}^{3}, n$-dodecane $=100 \mathrm{~mL}$, catalysts $=0.5(\mathrm{w} / \mathrm{v}) \%, 543 \mathrm{~K}$, and initial hydrogen pressure $=20$ bars.

1.7Ni2.4MoAl, $2.4 \mathrm{Ni} 1.7 \mathrm{MoAl}$, and $3.1 \mathrm{Ni1} .0 \mathrm{MoAl}$, respectively. With respect to $4.1 \mathrm{NiAl}$, the initial reaction rate enhancement factors were $1.8,3.3,5.7$, and 6.9 for $1.0 \mathrm{Ni} 3.1 \mathrm{MoAl}, 1.7 \mathrm{Ni} 2.4 \mathrm{MoAl}, 2.4 \mathrm{Ni} 1.7 \mathrm{MoAl}$, and $3.1 \mathrm{Ni} 1.0-$ $\mathrm{MoAl}$, respectively. The $\mathrm{HDO}$ of $\mathrm{C}_{17}-\mathrm{COOH}$ was also performed using $4.1 \mathrm{MoAl}$ under similar reaction conditions. The conversion of $\mathrm{C}_{17}-\mathrm{COOH}$ was, however, negligible over 4.1MoAl. The higher catalytic activity of NiMo compared to that of the $\mathrm{Ni}$ catalyst was thus mainly due to the synergetic effect of $\mathrm{Ni}$ and $\mathrm{Mo}$ and formation of highly active NiMo alloy species. The powder XRD pattern also revealed the presence of NiMo alloy and $\mathrm{NiMoO}_{4}$ species in reduced and calcined NiMo catalysts, respectively (Figure 2). Raman spectra further confirmed the existence of $\mathrm{NiMoO}_{4}$ species in calcined NiMo catalysts (Figure 1). The presence of catalytically inactive bulk $\mathrm{Ni}$ in $4.1 \mathrm{NiAl}$ might be an additional factor for its lower catalytic activity (Figure 3A).

For the NiMo catalyst with high $\mathrm{Ni}$ content such as $3.1 \mathrm{Ni} 1.0 \mathrm{MoAl}$ and $2.4 \mathrm{Ni1} .7 \mathrm{MoAl}$, both $\mathrm{Ni}$ and $\mathrm{NiMo}$ alloy species coexist as observed from powder XRD (Figure 2B). 
Table 2. Effect of Ni/Mo Mole Ratio on Product Distribution ${ }^{a}$

\begin{tabular}{|c|c|c|c|c|c|c|c|c|c|c|}
\hline \multirow[b]{2}{*}{ Catalyst } & all products & \multicolumn{9}{|c|}{ product distribution at $65 \%$ conversion of stearic acid, wt $\%$} \\
\hline & $\mathrm{C}_{15}$ & $\mathrm{C}_{16}$ & $\mathrm{C}_{17}$ & $\mathrm{C}_{18}$ & $\mathrm{C}_{17}-\mathrm{CHO}$ & $\mathrm{C}_{18}-\mathrm{OH}$ & $\mathrm{C}_{15}$ & $\mathrm{C}_{16}$ & $\mathrm{C}_{17}$ & $\mathrm{C}_{18}$ \\
\hline $4.1 \mathrm{NiAl}$ & 0.4 & 3.7 & 61.0 & 0.1 & & 34.8 & 0.6 & 5.6 & 93.6 & 0.2 \\
\hline $1.0 \mathrm{Ni} 3.1 \mathrm{MoAl}$ & 0 & 0.1 & 3.6 & 6.1 & 1.3 & 88.8 & 0 & 1.0 & 36.7 & 62.3 \\
\hline $1.7 \mathrm{Ni} 2.4 \mathrm{MoAl}$ & 0 & 0.1 & 5.6 & 6.3 & 1.4 & 85.4 & 0 & 1.6 & 46.3 & 52.1 \\
\hline $2.4 \mathrm{Ni} 1.7 \mathrm{MoAl}$ & 0.1 & 0.1 & 15.1 & 11.5 & 1.8 & 71.4 & 0.4 & 0.4 & 56.3 & 42.9 \\
\hline 3.1Ni1.0MoAl & 0.2 & 0.2 & 42.1 & 18.9 & 0.9 & 37.7 & 0.3 & 0.3 & 68.6 & 30.8 \\
\hline
\end{tabular}

The catalytic activity of these catalysts was thus due to both $\mathrm{Ni}$ and NiMo alloy species. On the other hand, the NiMo catalyst with high Mo content (1.7Ni2.4MoAl and 1.0Ni3.1MoAl), only NiMo alloy species was observed in powder XRD (Figure 2B). The catalytic activity of these catalysts was thus mainly due to NiMo alloy species. The TPR profile of the NiMo catalyst too showed that the reduction peak corresponding to $\mathrm{NiMoO}_{4}$ species was weak for both high and low $\mathrm{Ni}$ content (3.1Ni1.0MoAl and $1.0 \mathrm{Ni} 3.1 \mathrm{MoAl}$ ) and quite intense for moderate $\mathrm{Ni}$ and $\mathrm{Mo}$ content $(2.4 \mathrm{Ni} 1.7 \mathrm{MoAl}$ and $1.7 \mathrm{Ni} 2.4-$ MoAl) (Figure 3A). The increasing trend of catalytic activity of the NiMo catalyst with increasing $\mathrm{Ni}$ content up to $2.4 \mathrm{Ni} 1.7 \mathrm{MoAl}$ was thus due to the enrichment of highly active NiMo alloy species. The activity of $3.1 \mathrm{Ni1} .0 \mathrm{MoAl}$ was, however, not enhanced much compared to $2.4 \mathrm{Ni} 1.7 \mathrm{MoAl}$ as observed from the initial reaction rate enhancement factor.

Table 2 shows the effect of $\mathrm{Ni} / \mathrm{Mo}$ (mole) on the product distribution for a fixed conversion of $\mathrm{C}_{17}-\mathrm{COOH}$. For 4.1NiAl, the $\mathrm{C}_{17}$ alkane was the primary hydrocarbon product with an insignificant quantity of the $\mathrm{C}_{18}$ alkane. This result indicates that the reaction primarily follows the decarbonylation pathway over the $\mathrm{Ni}$ catalyst. On the other hand, the wt $\%$ of the $\mathrm{C}_{18}$ alkane was increased with increasing Mo content in NiMo catalysts with the simultaneous decrease in the $C_{17}$ alkane. The $\mathrm{C}_{17}$ alkane was the dominated hydrocarbon product for NiMo catalysts with high $\mathrm{Ni}$ content such as 3.1Ni1.0MoAl and 2.4Ni1.7MoAl. The $\mathrm{C}_{18}$ alkane was, however, observed as the leading hydrocarbon product for the NiMo catalyst with high Mo content such as $1.7 \mathrm{Ni} 2.4 \mathrm{MoAl}$ and 1.0Ni3.1MoAl. Powder XRD of the reduced NiMo catalyst exhibited the decline in intensity of $\mathrm{Ni}$ diffraction peaks with increasing Mo content and disappeared in $1.0 \mathrm{Ni} 3.1 \mathrm{MoAl}$ (Figure 2B). On the other hand, the NiMo alloy diffraction peaks were intensified with increasing Mo content up to 2.4Ni1.7MoAl (Figure 2B). These results indicate that the reaction follows two different pathways simultaneously over two different active sites present in the NiMo catalyst. The reaction follows the decarbonylation pathway over the Ni sites and $\mathrm{HDO}$ route over NiMo alloy species.

At $65 \%$ conversion of $\mathrm{C}_{17}-\mathrm{COOH}$, the wt $\%$ of $\mathrm{C}_{18}-\mathrm{OH}$ was quite high with the insignificant quantity of alkanes over NiMo catalysts (Table 2). Moreover, the wt $\%$ of $\mathrm{C}_{18}-\mathrm{OH}$ was enhanced with increasing Mo content in the catalyst. For a better understanding of catalytic activity, the wt $\%$ of alkane $\left(\mathrm{C}_{15}-\mathrm{C}_{18}\right)$ product at various conversions of $\mathrm{C}_{17}-\mathrm{COOH}$ was calculated as presented in Figure 4B. The NiMo catalyst with the highest Mo content (1.0Ni3.1MoAl) exhibited the lowest catalytic activity for converting intermediate oxygenated compounds $\left(\mathrm{C}_{18}-\mathrm{OH}\right.$ and $\left.\mathrm{C}_{17}-\mathrm{CHO}\right)$ to alkanes. The catalytic activity toward alkanes was increased with increasing
$\mathrm{Ni}$ content in the NiMo catalyst. Despite the lowest conversion of $\mathrm{C}_{17}-\mathrm{COOH}$ (Figure 4A), 4.1NiAl showed the highest catalytic activity toward alkanes. This result shows that reduction of $\mathrm{C}_{17}-\mathrm{COOH}$ to $\mathrm{C}_{18}-\mathrm{OH}$ is quite fast over NiMo alloy species compared to $\mathrm{Ni}$ sites of the catalyst, leading to the higher conversion of $\mathrm{C}_{17}-\mathrm{COOH}$ over NiMo catalysts. The conversion of $\mathrm{C}_{18}-\mathrm{OH}$ to alkanes is, however, relatively fast over $\mathrm{Ni}$ center than $\mathrm{NiMo}$ alloy species, resulting in higher wt \% of the alkane product over the Ni catalyst. A small quantity of $\mathrm{C}_{17}-\mathrm{CHO}$ was further noticed over the NiMo catalyst. $\mathrm{C}_{17}-\mathrm{CHO}$ was, however, absent over $4.1 \mathrm{NiAl}$. It might be due to the faster rate of decarbonylation of $\mathrm{C}_{17}-$ $\mathrm{CHO}$ over $\mathrm{Ni}$ center of the catalyst.

The optimum Ni/Mo (mole) in the NiMo catalyst can be deduced based on either catalytic activity or selectivity to hydrocarbon products. $3.1 \mathrm{Ni} 1.0 \mathrm{MoAl}$ showed the highest catalytic activity (Figure 4), and hence, it might appear as the best catalyst. On the other hand, the $\mathrm{C}_{17}$ alkane was the leading hydrocarbon product over $3.1 \mathrm{Ni1} .0 \mathrm{MoAl}$ and $2.4 \mathrm{Ni} 1.7 \mathrm{MoAl}$ (decarbonylation route), whereas the $\mathrm{C}_{18}$ alkane was the dominating hydrocarbon product over $1.7 \mathrm{Ni} 2.4 \mathrm{MoAl}$ and 1.0Ni3.1MoAl (HDO route) (Table 2). Therefore, 3.1Ni1.0$\mathrm{MoAl}$ and 1.0Ni3.1MoAl may apparently be deliberated as the suitable catalysts for $\mathrm{C}_{17}$ and $\mathrm{C}_{18}$ alkane-rich products, respectively. The formation of the $C_{17}$ alkane is, however, associated with loss of one carbon with a slightly lower yield of green diesel. On the basis of this factor, $1.0 \mathrm{Ni3}$.1MoAl may be considered as the appropriate catalyst for selective HDO of fatty acids. The decarbonylation route, however, consumes less hydrogen than the HDO route (Scheme 1). On the basis of this consideration, $3.1 \mathrm{Ni1} .0 \mathrm{MoAl}$ may be considered as the suitable catalyst for selective decarbonylation of fatty acids. On the other hand, green diesel with mixed hydrocarbons is desirable to obtain better fuel properties. The ratio of $\mathrm{C}_{17} / \mathrm{C}_{18}$ was about 1.3 over $2.4 \mathrm{Ni} 1.7 \mathrm{MoAl}$. Therefore, $2.4 \mathrm{Ni} 1.7 \mathrm{MoAl}$ was considered as the optimum catalyst in the present study. $\mathrm{Ni}$ /Mo (mole) of 3:2 was thus considered for the remaining studies.

2.3.2. Effect of Metal Loading. For a fixed Ni/Mo (mole) of 3:2, metal $(\mathrm{Ni}+\mathrm{Mo})$ loading in the NiMo catalyst was varied to obtain optimum metal loading. Figure 5 shows the conversion of $\mathrm{C}_{17}-\mathrm{COOH}$ over these catalysts. The conversion of $\mathrm{C}_{17}-\mathrm{COOH}$ was improved with increasing metal loading. At $60 \mathrm{~min}$ of reaction time, the conversion of $\mathrm{C}_{17}-\mathrm{COOH}$ was about $41 \%$ over $0.9 \mathrm{Ni} 0.6 \mathrm{MoAl}$ and reached about $72 \%$ for $2.4 \mathrm{Ni} 1.7 \mathrm{MoAl}$. The initial reaction rates were $1.5 \times 10^{-5}, 1.7 \times 10^{-5}, 1.9 \times 10^{-5}$, and $2.6 \times 10^{-5} \mathrm{kmol} / \mathrm{m}^{3} \mathrm{~s}$ over $0.9 \mathrm{Ni0} .6 \mathrm{MoAl}, 1.2 \mathrm{Ni0} .8 \mathrm{MoAl}, 1.8 \mathrm{Ni} 1.2 \mathrm{MoAl}$, and $2.4 \mathrm{Ni} 1.7 \mathrm{MoAl}$, respectively. The initial reaction rate enhancement factors were 1.1, 1.3, and 1.8 for increasing metal loading 


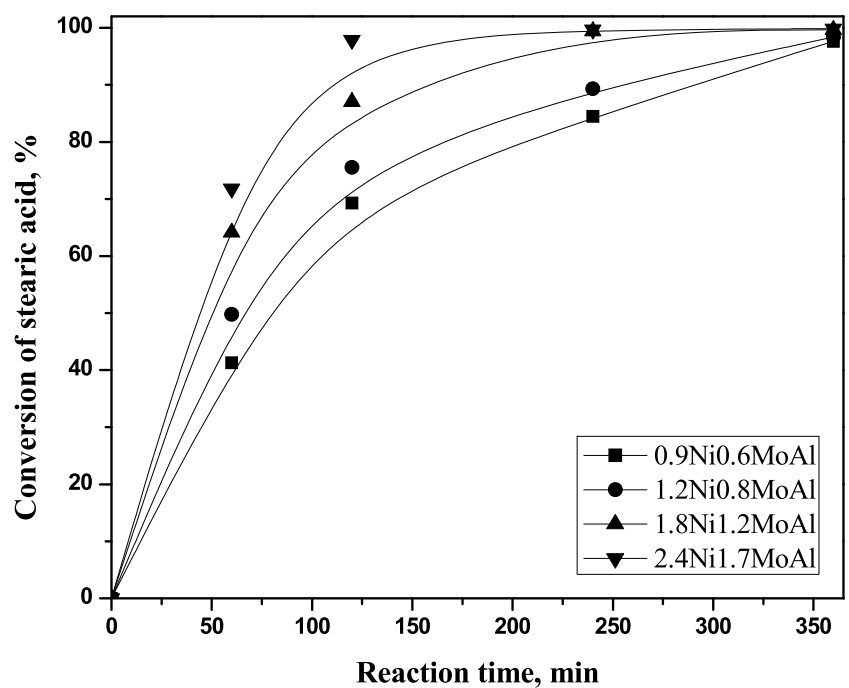

Figure 5. Effect of metals loading on conversion of stearic acid. Reaction conditions: concentration of stearic acid $=0.18 \mathrm{kmol} / \mathrm{m}^{3}, n$ dodecane $=100 \mathrm{~mL}$, catalysts $=0.5(\mathrm{w} / \mathrm{v}) \%, 573 \mathrm{~K}$, and initial hydrogen pressure $=20$ bars.

from 1.5 to $4.1 \mathrm{mmol} / \mathrm{g}$ alumina, respectively. The increase in catalytic activity with increasing metal loading was due to the increase in active sites ( $\mathrm{Ni}$ and NiMo alloy species) in the reduced NiMo catalyst (Figure S1B). The increase in the concentration of $\mathrm{Ni}$ and NiMo alloy species with increasing metal loading is also reflected by the increasing trend of the metallic surface area per gram of the catalyst (Table 1). Table 3 shows the effect of metal loading on wt $\%$ of products. The wt $\%$ of $\mathrm{C}_{18}-\mathrm{OH}$ was dropped with increasing metal loading with the simultaneous increase in wt $\%$ of alkanes. The catalytic activity was enhanced with increasing metal loading, leading to the increase in the conversion of $\mathrm{C}_{18}-\mathrm{OH}$ to alkanes. The product distribution was, however, practically unaffected by metal loading excepting $2.4 \mathrm{Ni} 1.7 \mathrm{MoAl}$. The wt $\%$ of the $\mathrm{C}_{17}$ alkane was, however, dominated over $2.4 \mathrm{Ni1} .7 \mathrm{MoAl}$. It may be due to the appreciable amount of

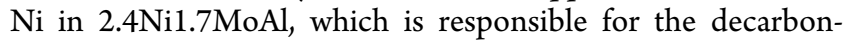
ylation route. The Ni was detected in powder $\mathrm{XRD}$ of reduced 2.4Ni1.7MoAl and $1.8 \mathrm{Ni1} .2 \mathrm{MoAl}$ only (Figure $\mathrm{S} 1 \mathrm{~B}$ ).

2.3.3. Reproducibility, Recyclability, and Regeneration Ability of $2.4 \mathrm{Ni}$.7MoAl. Two separate reaction runs were conducted under similar reaction conditions to demonstrate the reproducibility of reaction results as shown in Table 4. The conversion of $\mathrm{C}_{17}-\mathrm{COOH}$ and product distribution was almost similar in these two reaction runs. These results confirmed the repeatability of reaction results. To check the recyclability, the spent catalyst from these reaction mixtures was filtered and repeatedly washed with ethanol to remove adsorbed organic compounds. The filtered catalyst was then dried overnight at $373 \mathrm{~K}$. Another reaction run was then carried out using this dried spent catalyst. The conversion of $\mathrm{C}_{17}-\mathrm{COOH}$ over the dried spent catalyst was much lesser than the fresh catalyst. The lower catalytic activity of the dried spent catalyst might be due to the carbonaceous deposition on the active sites. The dried spent catalyst was then regenerated by calcination and reduction at $973 \mathrm{~K}$. The activity of this regenerated spent catalyst was subsequently tested for the $\mathrm{HDO}$ of $\mathrm{C}_{17}-\mathrm{COOH}$. The conversion of $\mathrm{C}_{17}-\mathrm{COOH}$ and wt $\%$ of products over the regenerated spent catalyst was quite similar to that of the fresh catalyst (Table 4). These results demonstrate the regeneration ability of the NiMo catalyst for the $\mathrm{HDO}$ of $\mathrm{C}_{17}-\mathrm{COOH}$.

2.4. Kinetic Model. In this work, we proposed a kinetic model for the $\mathrm{HDO}$ of $\mathrm{C}_{17}-\mathrm{COOH}(\mathrm{A})$ over NiMo catalysts based on the reaction of Scheme 1. The reaction was assumed as first order with respect to compounds in the liquid phase and partial pressure of hydrogen $\left(p_{\mathrm{H}_{2}}\right)$. The dehydrogenation of $\mathrm{C}_{18}-\mathrm{OH}(\mathrm{B})$ to $\mathrm{C}_{17}-\mathrm{CHO}(\mathrm{C})$ is a reversible reaction. However, we observed only a small quantity of $\mathrm{C}_{17}-\mathrm{CHO}$ in this work. This was due to the faster rate of the decarbonylation reaction. A pseudo-steady-state hypothesis was thus adopted for the calculation of $\mathrm{C}_{17}-\mathrm{CHO}$ concentration during the reaction (eq 1 ).

$$
\begin{gathered}
\frac{\mathrm{d} C_{\mathrm{C}}}{\mathrm{d} t}=0=k_{2} C_{\mathrm{B}}-\left(k_{2} / k_{\mathrm{eq}}\right) C_{\mathrm{C}_{\mathrm{H}_{2}}}-k_{4} C_{\mathrm{C}} \Rightarrow C_{\mathrm{C}} \\
=\frac{k_{2} C_{\mathrm{B}}}{\left(k_{2} / k_{\mathrm{eq}}\right) p_{\mathrm{H}_{2}}+k_{4}} \quad \text { where } k_{\mathrm{eq}}=k_{2} / k_{-2}
\end{gathered}
$$

Equations 2-5 show the rate of formation of $\mathrm{A}, \mathrm{B}, \mathrm{C}_{18}$ alkane (D), and $\mathrm{C}_{17}$ alkane (E), respectively.

$$
\begin{aligned}
\frac{\mathrm{d} C_{\mathrm{A}}}{\mathrm{d} t} & =-k_{1} C_{\mathrm{A}} p_{\mathrm{H}_{2}} \\
\frac{\mathrm{d} C_{\mathrm{B}}}{\mathrm{d} t} & =k_{1} C_{\mathrm{A}} p_{\mathrm{H}_{2}}-k_{2} C_{\mathrm{B}}+\left(k_{2} / k_{\mathrm{eq}}\right) C_{\mathrm{C}_{\mathrm{H}_{2}}}-k_{3} C_{\mathrm{B}} \\
\frac{\mathrm{d} C_{\mathrm{D}}}{\mathrm{d} t} & =k_{3} C_{\mathrm{B}} \\
\frac{\mathrm{d} C_{\mathrm{E}}}{\mathrm{d} t} & =k_{4} C_{\mathrm{C}}
\end{aligned}
$$

We calculated the equilibrium constant $\left(k_{\text {eq }}\right)$ of the $\mathrm{C}_{18}-\mathrm{OH}$ dehydrogenation reaction based on standard Gibbs free energy

\begin{tabular}{|c|c|c|c|c|c|c|c|c|c|c|}
\hline \multirow[b]{2}{*}{ catalyst } & \multicolumn{10}{|c|}{ product distribution at $70 \%$ conversion of stearic acid, wt $\%$} \\
\hline & $\mathrm{C}_{15}$ & $\mathrm{C}_{16}$ & $\mathrm{C}_{17}$ & $\mathrm{C}_{18}$ & $\mathrm{C}_{17}-\mathrm{CHO}$ & $\mathrm{C}_{18}-\mathrm{OH}$ & $\mathrm{C}_{15}$ & $\mathrm{C}_{16}$ & $\mathrm{C}_{17}$ & $\mathrm{C}_{18}$ \\
\hline $0.9 \mathrm{Ni} 0.6 \mathrm{MoAl}$ & 0 & 0 & 2.9 & 3.2 & 1.4 & 92.5 & 0 & 0 & 47.5 & 52.5 \\
\hline $1.2 \mathrm{Ni} 0.8 \mathrm{MoAl}$ & 0 & 0.1 & 8.4 & 9.4 & 1.0 & 81.1 & 0 & 0.6 & 46.9 & 52.5 \\
\hline $1.8 \mathrm{Ni} 1.2 \mathrm{MoAl}$ & 0.1 & 0.2 & 10.6 & 10.9 & 1.4 & 76.8 & 0 & 1.4 & 48.6 & 50.0 \\
\hline $2.4 \mathrm{Nil} .7 \mathrm{MoAl}$ & 0.2 & 0.3 & 16.7 & 12.6 & 1.4 & 68.8 & 0 & 1.7 & 56.0 & 42.3 \\
\hline
\end{tabular}
change $\left(\Delta G_{298 \mathrm{~K}}^{0}=34.7 \mathrm{~kJ} / \mathrm{mol}\right): \Delta G_{298 \mathrm{~K}}^{0}=-R T \ln \left(k_{\mathrm{eq}}\right)$. The hydrogen is consumed in the $\mathrm{HDO}$ of $\mathrm{C}_{17}-\mathrm{COOH}$. The partial pressure of hydrogen thus reduces with the progress of the reaction. It was calculated based on the following equation:

Table 3. Effect of Metal Loadings on Product Distribution ${ }^{a}$

${ }^{a}$ All reaction conditions are same as Figure 5. 
Table 4. Reproducibility, Recyclability, and Regeneration Ability over 2.4Ni1.7MoAl for the HDO of Stearic Acid ${ }^{a}$

\begin{tabular}{|c|c|c|c|c|c|c|c|}
\hline experiment & conversion of stearic acid, $\%^{b}$ & $\mathrm{C}_{15}$ & $\mathrm{C}_{16}$ & $\mathrm{C}_{17}$ & $\mathrm{C}_{18}$ & $\mathrm{C}_{17}-\mathrm{CHO}$ & $\mathrm{C}_{18}-\mathrm{OH}$ \\
\hline \multicolumn{8}{|c|}{ Reproducibility } \\
\hline run 1 & 97.5 & 0 & 0.4 & 27.5 & 20.9 & 0.7 & 50.5 \\
\hline run 2 & 94.2 & 0 & 0.8 & 26.9 & 20.3 & 0.8 & 51.2 \\
\hline \multicolumn{8}{|c|}{ Recyclability of Spent Catalyst } \\
\hline run 3 & 77.7 & 0 & 0 & 9.7 & 5.2 & 1.1 & 84.0 \\
\hline \multicolumn{8}{|c|}{ Reusability of Regenerated Spent Catalyst } \\
\hline run 4 & 98.5 & 0.1 & 0.2 & 27.9 & 22.8 & 0.6 & 48.4 \\
\hline
\end{tabular}

${ }^{a}$ Reaction conditions: concentration of stearic acid $=0.18 \mathrm{kmol} / \mathrm{m}^{3} . n$-dodecane $=100 \mathrm{~mL}$, catalysts $=0.5(\mathrm{w} / \mathrm{v}) \%$, $543 \mathrm{~K}$, and initial hydrogen pressure $=20$ bars. ${ }^{b}$ Conversion of stearic acid at $120 \mathrm{~min}$.

$$
p_{\mathrm{H}_{2}}=p_{\mathrm{H}_{2}}^{0}-v\left(2 C_{\mathrm{B}}+C_{\mathrm{C}}+3 C_{\mathrm{D}}+C_{\mathrm{E}}\right) R T / V
$$

where $v$ and $V$ represent the volume of liquid and gas, respectively.

The rate constants of the kinetic model were calculated using kinetic data by a nonlinear regression algorithm. The ordinary differential equations (eqs 2-5) were integrated using the RK4 method. The rate constants were estimated by minimizing the below objective function.

$$
\begin{aligned}
& \mathrm{OF}= \\
& \sqrt{\sum_{i=1}^{n}\left(\left(C_{\mathrm{A}, i}^{\mathrm{E}}-C_{\mathrm{A}, i}^{\mathrm{C}}\right)^{2}+\left(C_{\mathrm{B}, i}^{\mathrm{E}}-C_{\mathrm{B}, i}^{\mathrm{C}}\right)^{2}+\left(C_{\mathrm{D}, i}^{\mathrm{E}}-C_{\mathrm{D}, i}^{\mathrm{C}}\right)^{2}+\left(C_{\mathrm{E}, i}^{\mathrm{E}}-C_{\mathrm{E}, i}^{\mathrm{C}}\right)^{2}\right)}
\end{aligned}
$$

2.5. Kinetic Studies. $\mathrm{HDO}$ of $\mathrm{C}_{17}-\mathrm{COOH}$ was carried out at five different temperatures $(493-553 \mathrm{~K})$ over $2.4 \mathrm{Ni1} .7 \mathrm{MoAl}$ as shown in Figure 6. The conversion of $\mathrm{C}_{17}-\mathrm{COOH}$ was

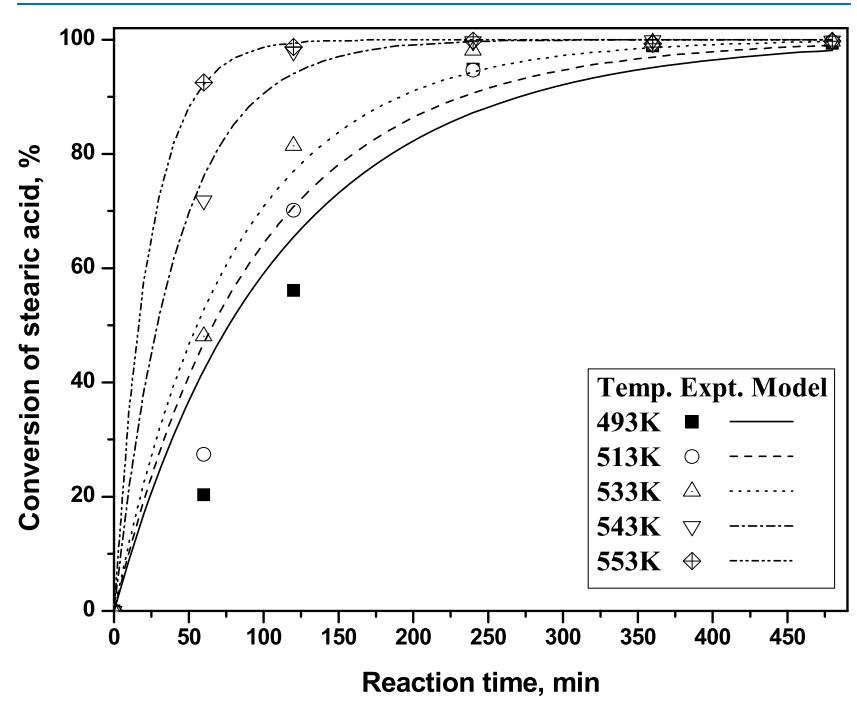

Figure 6. Effect of reaction temperature on conversion of stearic acid. Reaction conditions: concentration of stearic acid $=0.18 \mathrm{kmol} / \mathrm{m}^{3}, n$ dodecane $=100 \mathrm{~mL}$, catalysts $=0.5(\mathrm{w} / \mathrm{v}) \% 2.4 \mathrm{Ni} 1.7 \mathrm{MoAl}$, and initial hydrogen pressure $=20$ bars.

enhanced with increasing reaction temperature as expected. The conversion of $\mathrm{C}_{17}-\mathrm{COOH}$ at $60 \mathrm{~min}$ of reaction time was about $20 \%$ at $493 \mathrm{~K}$ and increased to about $92 \%$ at $553 \mathrm{~K}$. The initial reaction rates were $8.8 \times 10^{-6}, 1.2 \times 10^{-5}, 1.4 \times 10^{-5}$, $2.6 \times 10^{-5}$, and $2.9 \times 10^{-5} \mathrm{kmol} / \mathrm{m}^{3} \mathrm{~s}$ at $493,513,533,543$, and $553 \mathrm{~K}$, respectively. With respect to $493 \mathrm{~K}$, the initial reaction rate was enhanced by factors of $1.4,1.6,2.9$, and 3.3 for $513,533,543$, and $553 \mathrm{~K}$, respectively. The apparent activation energy was found to be $38.7 \mathrm{~kJ} / \mathrm{mol}$ from the
Arrhenius plot of $\ln$ (initial rate) versus $1 / T$. Table 5 shows the effect of reaction temperature on wt \% of products for a fixed conversion of $\mathrm{C}_{17}-\mathrm{COOH}$. The wt $\%$ of $\mathrm{C}_{18}-\mathrm{OH}$ was dropped with increasing reaction temperature with the concurrent increase in wt \% of alkanes. With increasing reaction temperature, the reaction rate was enhanced, resulting in the increase in conversion of $\mathrm{C}_{18}-\mathrm{OH}$ to alkanes.

The rate constants of the kinetic model (eqs 1-7) were then obtained based on these kinetic data. The pre-exponential factor and activation energy were calculated using the Arrhenius law. The activation energy for the rate constant, $k_{1}$, was quite low compared to the other rate constants (Table 6). The reduction of $\mathrm{C}_{17}-\mathrm{COOH}$ to $\mathrm{C}_{18}-\mathrm{OH}$ is thus quite a fast reaction, resulting in the high conversion of $\mathrm{C}_{17}-\mathrm{COOH}$ even at a low reaction temperature. Because of high activation energy, the conversion of $\mathrm{C}_{18}-\mathrm{OH}$ to alkanes (by decarbonylation and HDO route) was appreciable only at higher reaction temperatures especially at $543 \mathrm{~K}$ and above (Table 5). Therefore, the wt $\%$ of alkanes became significant at higher reaction temperatures only. The conversion of $\mathrm{C}_{17}-\mathrm{COOH}$ was further calculated based on these rate constants. The calculated $\mathrm{C}_{17}-\mathrm{COOH}$ conversion was then matched with the reaction results as shown in Figure 6. The calculated $\mathrm{C}_{17}-$ $\mathrm{COOH}$ conversion matched reasonably well with reaction results.

\section{CONCLUSIONS}

The $\mathrm{NiMoO}_{4}$ and NiMo alloy species were observed in calcined and reduced NiMo catalysts, respectively. These species were significant in NiMo catalysts with $\mathrm{Ni} / \mathrm{Mo}$ (mole) of $2: 3$ and 3:2. On the other hand, the $\mathrm{Ni}$ content was substantial in the NiMo catalyst with high $\mathrm{Ni} / \mathrm{Mo}$ (mole) and decreased gradually with the drop in $\mathrm{Ni} / \mathrm{Mo}$ (mole). The activity of the NiMo catalyst for the $\mathrm{HDO}$ of $\mathrm{C}_{17}-\mathrm{COOH}$ was enhanced with increasing $\mathrm{Ni} / \mathrm{Mo}$ (mole). It was due to the enrichment of highly active NiMo alloy species with increasing $\mathrm{Ni} / \mathrm{Mo}$ (mole). The reaction followed two RPs simultaneously over two different active centers present in the catalyst: decarbonylation over $\mathrm{Ni}$ and $\mathrm{HDO}$ over NiMo alloy species. The $\mathrm{C}_{17}$ alkane was the primary hydrocarbon product over 4.1NiAl. The $\mathrm{C}_{18}$ alkane was the dominating hydrocarbon product over the NiMo catalyst with $\mathrm{Ni} / \mathrm{Mo}$ (mole) of $1: 3$ and 2:3. The $\mathrm{C}_{17}$ alkane was, however, the leading hydrocarbon product for higher $\mathrm{Ni} / \mathrm{Mo}$ (mole). For a fixed Ni/Mo (mole), the catalytic activity of the NiMo catalyst was enhanced with increasing metal $(\mathrm{Ni}+\mathrm{Mo})$ loading without altering the product distribution. A power law-based kinetic model was established based on the proposed reaction scheme. The activation energy was relatively low for the reduction of $\mathrm{C}_{17}$ $\mathrm{COOH}$ to $\mathrm{C}_{18}-\mathrm{OH}(12.1 \mathrm{kcal} / \mathrm{mol})$ compared to the 
Table 5. Effect of Reaction Temperature on Product Distribution ${ }^{a}$

\begin{tabular}{|c|c|c|c|c|c|c|c|c|c|c|}
\hline \multirow[b]{2}{*}{ temperature, $\mathrm{K}$} & \multicolumn{10}{|c|}{ product distribution at $70 \%$ conversion of stearic acid, wt $\%$} \\
\hline & $\mathrm{C}_{15}$ & $\mathrm{C}_{16}$ & $\mathrm{C}_{17}$ & $\mathrm{C}_{18}$ & $\mathrm{C}_{17}-\mathrm{CHO}$ & $\mathrm{C}_{18}-\mathrm{OH}$ & $\mathrm{C}_{15}$ & $\mathrm{C}_{16}$ & $\mathrm{C}_{17}$ & $\mathrm{C}_{18}$ \\
\hline 493 & 0 & 0 & 1 & 1.1 & 0.6 & 97.3 & 0 & 0 & 47.6 & 52.4 \\
\hline 513 & 0 & 0 & 1.9 & 1.8 & 0.8 & 95.7 & 0 & 0 & 51.4 & 48.6 \\
\hline 533 & 0 & 0 & 3.7 & 3.1 & 1.2 & 91.7 & 0 & 0 & 54.4 & 45.6 \\
\hline 543 & 0.2 & 0.3 & 16.7 & 12.6 & 1.4 & 68.8 & 0 & 1.7 & 56.0 & 42.3 \\
\hline 553 & 0.1 & 0.3 & 24.1 & 23.2 & 1.5 & 51.1 & 0 & 0.6 & 50.5 & 48.6 \\
\hline
\end{tabular}

Table 6. Estimated Parameters of the Kinetic Model

\begin{tabular}{|c|c|c|c|c|c|}
\hline temperature, $\mathrm{K}$ & $k_{1} \times 10^{5}, \mathrm{~s}^{-1} \mathrm{bar}^{-1}$ & $k_{2} \times 10^{3}, \mathrm{~s}^{-1}$ & $k_{3} \times 10^{5}, \mathrm{~s}^{-1}$ & $k_{4}, \mathrm{~s}^{-1}$ & $k_{\text {eq }} \times 10^{4}$ \\
\hline 493 & 0.417 & 1.08 & 0.283 & 0.67 & 2.11 \\
\hline 513 & 0.467 & 1.25 & 0.633 & 1.17 & 2.93 \\
\hline 533 & 0.533 & 1.58 & 1.33 & 1.50 & 3.97 \\
\hline 543 & 1.03 & 2.33 & 6.00 & 7.08 & 4.59 \\
\hline 553 & 1.83 & 5.67 & 11.17 & 9.58 & 5.28 \\
\hline pre-exponential factor, unit of $\mathrm{k}$ & $8.00 \times 10^{-1}$ & $6.18 \times 10^{17}$ & $1.39 \times 10^{24}$ & $3.62 \times 10^{25}$ & \\
\hline activation energy, $\mathrm{kcal} / \mathrm{mol}$ & 12.1 & 45.9 & 66.2 & 57.2 & \\
\hline$R^{2}$ & 0.74 & 0.84 & 0.92 & 0.88 & \\
\hline
\end{tabular}

decarbonylation of $\mathrm{C}_{17}-\mathrm{CHO}(57.2 \mathrm{kcal} / \mathrm{mol})$ and $\mathrm{HDO}$ of the $\mathrm{C}_{18}-\mathrm{OH}(66.2 \mathrm{kcal} / \mathrm{mol})$ route. The wt $\%$ of alkanes was thus trivial at low reaction temperature and enhanced with an increase in the reaction temperature.

\section{EXPERIMENTAL SECTION}

4.1. Catalyst Preparation. Alumina ( $\mathrm{Al}$ )-supported NiMo catalysts are abbreviated as aNibMoAl, where $a$ and $b$ signify the millimoles of $\mathrm{Ni}$ and Mo per gram of support, respectively. These catalysts were prepared by an incipient wetness coimpregnation method. The metal precursors equivalent to $a$ and $b \mathrm{mmol} / \mathrm{g}$ alumina of $\mathrm{Ni}$ (nickel nitrate hexahydrate, $\geq 97 \%$, Merck Specialties Pvt. Ltd.) and Mo (ammonium molybdate tetrahydrate, $99.98 \%$, Sigma-Aldrich) were first dissolved in distilled water. The volume of water used in this method was slightly more than the pore volume of $\gamma-\mathrm{Al}_{2} \mathrm{O}_{3}$ (Alfa Aesar). This solution was then added dropwise to the measured quantity of $\gamma-\mathrm{Al}_{2} \mathrm{O}_{3}$ with constant stirring for about 1 h. This wet catalyst was first dried at ambient temperature, followed by drying in a hot-air oven at $373 \mathrm{~K}$ for about $12 \mathrm{~h}$. The dried catalyst was then calcined at $973 \mathrm{~K}$ for about $6 \mathrm{~h}$ in a muffle furnace. The calcined catalysts were finally reduced by hydrogen at $973 \mathrm{~K}$ for $3 \mathrm{~h}$ in a tubular furnace. These catalysts are represented as the NiMo catalyst throughout this article for simplicity of the discussion.

4.2. Catalyst Characterization. The catalysts were characterized to determine the specific surface area and pore volume (Micromeritics ASAP 2020), reducibility, reduction temperature $\left(T_{\max }\right)$, metal dispersion, and metallic surface area (Micromeritics AutoChem II 2920). For BET, the catalyst was degassed under vacuum $\left(10^{-5}\right.$ Torr $)$ at $523 \mathrm{~K}$ for $6 \mathrm{~h}$. The nitrogen adsorption/desorption isotherms were measured at $77 \mathrm{~K}$. The BET surface area was then calculated from nitrogen adsorption isotherm in the relative pressure $\left(P / P_{0}\right)$ range of $0.05-0.3$. The pore volume was considered as the volume of liquid nitrogen adsorbed at $P / P_{0}=1.0 \mathrm{ca}$. For $\mathrm{H}_{2}$-TPR studies, the calcined catalyst $(20 \mathrm{mg})$ was first pretreated by argon (30 $\mathrm{mL} / \mathrm{min}$ ) at $473 \mathrm{~K}$ for $3 \mathrm{~h}$. The $\mathrm{H}_{2}$-TPR studies were then carried out using $10 \mathrm{vol} \% \mathrm{H}_{2}-$ Ar gas mixture $(30 \mathrm{~mL} / \mathrm{min})$ in the temperature range of $323-1073 \mathrm{~K}$ with a heating rate of 5 $\mathrm{K} / \mathrm{min}$. For $\mathrm{H}_{2}$-pulse chemisorption studies, the calcined catalyst was first reduced by $10 \mathrm{vol} \% \mathrm{H}_{2}-\mathrm{Ar}(30 \mathrm{~mL} / \mathrm{min})$ at $923 \mathrm{~K}$ for $2 \mathrm{~h}$ and then pretreated using pure $\mathrm{He}(30 \mathrm{~mL} / \mathrm{min})$ at $323 \mathrm{~K}$ for $3 \mathrm{~h}$. The $\mathrm{H}_{2}$-pulse chemisorption studies of the reduced catalyst were then carried out at $323 \mathrm{~K}$ using 10 vol \% $\mathrm{H}_{2}-\mathrm{Ar}$ gas. The metal dispersion and metal surface area were obtained from the amount of hydrogen chemisorbed.

Powder XRD pattern of the catalysts was recorded in the $2 \theta$ range of $10-90^{\circ}$ in a Phillips X-ray diffractometer (X-PERT Pro PAN analytical) using $\mathrm{Cu} \mathrm{K} \alpha$ radiation $(\lambda=1.5418 \AA)$ at $45 \mathrm{kV}$ and $30 \mathrm{~mA}$ current with a scanning rate of $1 \% \mathrm{~min}$. The Raman spectra of calcined catalysts were obtained under ambient condition using a Raman spectrometer system (Bruker, Senterra) equipped with a confocal microscope and 1200 grooves $/ \mathrm{mm}$ grate. The samples were excited with a 532 $\mathrm{nm}$ laser $(20 \mathrm{~mW})$, and the spectra were acquired in the 200$1100 \mathrm{~cm}^{-1}$ region at a resolution of $20 \mathrm{~cm}^{-1}$. A thin wafer of the pure sample was made for Raman analysis. UV-vis-NIR spectra of the calcined NiMo catalysts were recorded in a UVvis-NIR spectrometer (PerkinElmer UV-vis-NIR spectrometer, Lamda-1050) equipped with diffuse reflectance accessories (Harrick scientific Products Inc., USA) in the wavelength range of $250-800 \mathrm{~nm}$ using $\mathrm{BaSO}_{4}$ as a reference under ambient condition.

4.3. Reaction Setup and Procedure. Catalytic HDO of $\mathrm{C}_{17}-\mathrm{COOH}$ ( $\geq 97 \%$, Merck Specialties Pvt. Ltd.) was studied in a high-pressure batch reactor. The reactor is enclosed in an electrically heated furnace. The reactor consists of a four-blade impeller, a thermocouple, and a temperature and rotations per minute regulator. The reactor was maintained within $\pm 1 \mathrm{~K}$ using a PID temperature controller. For a typical reaction, $5 \mathrm{~g}$ of $\mathrm{C}_{17}-\mathrm{COOH}\left(0.18 \mathrm{kmol} / \mathrm{m}^{3}\right)$ was dissolved in $100 \mathrm{~mL} n$ dodecane ( $\geq 99 \%$, Sigma-Aldrich). The $\mathrm{C}_{17}-\mathrm{COOH}$ solution and $0.5 \mathrm{~g}$ catalyst $(0.5(\mathrm{w} / \mathrm{v}) \%)$ were then added into the reactor. The hydrogen was purged a few times to remove air from the reactor. The reactor was initially pressurized to 20 bars hydrogen at room temperature. The reactor was heated to a specified reaction temperature at a constant stirring speed of 
$1200 \mathrm{rpm}$. The reactor pressure was increased to about $31 \mathrm{bar}$ at the reaction temperature of $543 \mathrm{~K}$. The initial liquid sample was taken immediately after attainment of the specified reaction temperature. The conversion of $\mathrm{C}_{17}-\mathrm{COOH}$ was calculated based on this initial reaction sample. Further reaction samples were collected at different reaction times. The products in the reaction sample were identified by GCMS (GCMS-QP2010 Ultra) and quantified using an off-line GC-FID (Shimadzu, GC-2014). ${ }^{4}$ The wt $\%$ of products and unreacted $\mathrm{C}_{17}-\mathrm{COOH}$ were calculated based on the known concentration of internal standard, $n$-dodecane. The product distribution term used in the article is expressed as wt \% of the individual products.

\section{ASSOCIATED CONTENT}

\section{S Supporting Information}

The Supporting Information is available free of charge on the ACS Publications website at DOI: 10.1021/acsomega.8b03592.

Powder XRD pattern of calcined and reduced NiMo catalysts with different metal $(\mathrm{Ni}+\mathrm{Mo})$ loading and $\mathrm{UV}$-vis spectra of NiMo catalysts with different $\mathrm{Ni} / \mathrm{Mo}$ mole ratios (PDF)

\section{AUTHOR INFORMATION}

\section{Corresponding Author}

*E-mail: sunil_maity@iith.ac.in. Phone: +91-40-2301-6075. Fax: +91-40-2301 6003 .

\section{ORCID}

Sunil K. Maity: 0000-0002-1832-5060

\section{Notes}

The authors declare no competing financial interest.

\section{ACKNOWLEDGMENTS}

We are thankful to the Department of Science and Technology, New Delhi, India, for funding this project (DST/TSG/AF/2010/65-G dated 17.11.2011).

\section{NOMENCLATURE}

aNibMoAl, catalyst with $a$ and $b \mathrm{mmol}$ of $\mathrm{Ni}$ and Mo metals per gram of $\gamma-\mathrm{Al}_{2} \mathrm{O}_{3}(\mathrm{Al})$, respectively; $\mathrm{C}_{17}-\mathrm{COOH}$, stearic acid; $\mathrm{C}_{17}-\mathrm{CHO}$, octadecanal; $\mathrm{C}_{18}-\mathrm{OH}$, 1-octadecanol; HDO, hydrodeoxygenation; $\mathrm{RP}$, reaction pathway

\section{REFERENCES}

(1) Maity, S. K. Opportunities, recent trends and challenges of integrated biorefinery: Part I. Renewable Sustainable Energy Rev. 2015, 43, 1427-1445.

(2) Government of India. National Policy on Biofuels, 2008.

(3) United Nations Climate Change. Kyoto Protocol. https:// unfccc.int/process-and-meetings/the-kyoto-protocol/what-is-thekyoto-protocol (accessed 2012).

(4) Kumar, P.; Yenumala, S. R.; Maity, S. K.; Shee, D. Kinetics of Hydrodeoxygenation of Stearic Acid Using Supported Nickel Catalysts: Effects of Supports. Appl. Catal., A 2014, 471, 28-38.

(5) Wang, W.-C.; Thapaliya, N.; Campos, A.; Stikeleather, L. F.; Roberts, W. L. Hydrocarbon Fuels from Vegetable Oils via Hydrolysis and Thermo-Catalytic Decarboxylation. Fuel 2012, 95, 622-629.

(6) Wang, H.; Lin, H.; Zheng, Y.; Ng, S.; Brown, H.; Xia, Y. KaolinBased Catalyst as a Triglyceride FCC Upgrading Catalyst with High Deoxygenation, Mild Cracking, and Low Dehydrogenation Performances. Catal. Today 2019, 319, 164-171.
(7) Furimsky, E. Catalytic Hydrodeoxygenation. Appl. Catal., A 2000, 199, 147-190.

(8) Bezergianni, S.; Dimitriadis, A.; Meletidis, G. Effectiveness of CoMo and NiMo Catalysts on Co-Hydroprocessing of Heavy Atmospheric Gas Oil-Waste Cooking Oil Mixtures. Fuel 2014, 125, 129-136.

(9) Ngaosuwan, K.; Lotero, E.; Suwannakarn, K.; Goodwin, J. G.; Praserthdam, P. Hydrolysis of Triglycerides Using Solid Acid Catalysts. Ind. Eng. Chem. Res. 2009, 48, 4757-4767.

(10) Liu, M.; Shi, Y.; Bi, Y.; Xing, E.; Wu, Y.; Huang, S.; Yang, M. Influence of Porosity on Product Distribution over Co/H-ZSM-22 Catalysts in the Upgrading of Palmitic Acid. Energy Technol 2018, 6, 406-415.

(11) Brillouet, S.; Baltag, E.; Brunet, S.; Richard, F. Deoxygenation of Decanoic Acid and Its Main Intermediates over Unpromoted and Promoted Sulfided Catalysts. Appl. Catal., B 2014, 148-149, 201-211.

(12) Bernas, H.; Eränen, K.; Simakova, I.; Leino, A.-R.; Kordás, K.; Myllyoja, J.; Mäki-Arvela, P.; Salmi, T.; Murzin, D. Y. Deoxygenation of Dodecanoic Acid under Inert Atmosphere. Fuel 2010, 89, 20332039.

(13) Coumans, A. E.; Hensen, E. J. M. A Model Compound (Methyl Oleate, Oleic Acid, Triolein) Study of Triglycerides Hydrodeoxygenation over Alumina-Supported NiMo Sulfide. Appl. Catal., B 2017, 201, 290-301.

(14) Ayodele, O. B.; Togunwa, O. S.; Abbas, H. F.; Daud, W. M. A. W. Preparation and Characterization of Alumina Supported NickelOxalate Catalyst for the Hydrodeoxygenation of Oleic Acid into Normal and Iso-Octadecane Biofuel. Energy Convers. Manage. 2014, $88,1104-1110$.

(15) Peroni, M.; Lee, I.; Huang, X.; Baráth, E.; Gutiérrez, O. Y.; Lercher, J. A. Deoxygenation of Palmitic Acid on Unsupported Transition-Metal Phosphides. ACS Catal. 2017, 7, 6331-6341.

(16) Yang, L.; Carreon, M. A. Deoxygenation of Palmitic and Lauric Acids over Pt/ZIF-67 Membrane/Zeolite 5A Bead Catalysts. ACS Appl. Mater. Interfaces 2017, 9, 31993-32000.

(17) Besse, X.; Schuurman, Y.; Guilhaume, N. Hydrothermal Conversion of Linoleic Acid and Ethanol for Biofuel Production. Appl. Catal., A 2016, 524, 139-148.

(18) Ding, S.; Li, Z.; Li, F.; Wang, Z.; Li, J.; Zhao, T.; Lin, H.; Chen, C. Catalytic Hydrogenation of Stearic Acid over Reduced NiMo Catalysts: Structure-activity Relationship and Effect of the Hydrogen-Donor. Appl. Catal., A 2018, 566, 146-154.

(19) Arora, P.; Ojagh, H.; Woo, J.; Grennfelt, E. L.; Olsson, L.; Creaser, D. Investigating the Effect of $\mathrm{Fe}$ as a Poison for Catalytic HDO over Sulfided NiMo Alumina Catalysts. Appl. Catal., B 2018, $227,240-251$.

(20) Boonyasuwat, S.; Tscheikuna, J. Co-Processing of Palm Fatty Acid Distillate and Light Gas Oil in Pilot-Scale Hydrodesulfurization Unit over Commercial CoMo/ $\mathrm{Al}_{2} \mathrm{O}_{3}$. Fuel 2017, 199, 115-124.

(21) Kaluža, L.; Kubička, D. The Comparison of Co , Ni , Mo , CoMo and NiMo Sulfided Catalysts in Rapseed Oil Hydrodeoxygenation. React. Kinet., Mech. Catal. 2017, 122, 333-341.

(22) Zhao, C.; Brück, T.; Lercher, J. A. Catalytic Deoxygenation of Microalgae Oil to Green Hydrocarbons. Green Chem. 2013, 15, $1720-1739$.

(23) Mondal, S.; Singuru, R.; Chandra Shit, S.; Hayashi, T.; Irle, S.; Hijikata, Y.; Mondal, J.; Bhaumik, A. Ruthenium NanoparticleDecorated Porous Organic Network for Direct Hydrodeoxygenation of Long-Chain Fatty Acids to Alkanes. ACS Sustainable Chem. Eng. 2017, 6, 1610-1619.

(24) Hachemi, I.; Murzin, D. Y. Kinetic Modeling of Fatty Acid Methyl Esters and Triglycerides Hydrodeoxygenation over Nickel and Palladium Catalysts. Chem. Eng. J. 2018, 334, 2201-2207.

(25) Patil, S. J.; Vaidya, P. D. On the Production of BioHydrogenated Diesel over Hydrotalcite-like Supported Palladium and Ruthenium Catalysts. Fuel Process. Technol. 2018, 169, 142-149.

(26) Janampelli, S.; Darbha, S. Effect of Support on the Catalytic Activity of $\mathrm{WO}_{\mathrm{x}}$ Promoted Pt in Green Diesel Production. Mol. Catal. 2018, 451, 125-134. 
(27) Kaylor, N.; Xie, J.; Kim, Y.-S.; Pham, H. N.; Datye, A. K.; Lee, Y.-K.; Davis, R. J. Vapor Phase Deoxygenation of Heptanoic Acid over Silica-Supported Palladium and Palladium-Tin Catalysts. J. Catal. 2016, 344, 202-212.

(28) Chen, H.; Zhang, X.; Zhang, J.; Wang, Q. Tuning the Decarboxylation Selectivity for Deoxygenation of Vegetable Oil over Pt-Ni Bimetal Catalysts via Surface Engineering. Catal. Sci. Technol. 2018, 8, 1126-1133.

(29) Imai, H.; Kimura, T.; Terasaka, K.; Li, X.; Sakashita, K.; Asaoka, S.; Al-Khattaf, S. S. Hydroconversion of Fatty Acid Derivative over Supported Ni-Mo Catalysts under Low Hydrogen Pressure. Catal. Today 2018, 303, 185-190.

(30) Santillan-Jimenez, E.; Loe, R.; Garrett, M.; Morgan, T.; Crocker, M. Effect of $\mathrm{Cu}$ Promotion on Cracking and Methanation during the Ni-Catalyzed Deoxygenation of Waste Lipids and Hemp Seed Oil to Fuel-like Hydrocarbons. Catal. Today 2018, 302, 261271.

(31) Srifa, A.; Kaewmeesri, R.; Fang, C.; Itthibenchapong, V.; Faungnawakij, K. $\mathrm{NiAl}_{2} \mathrm{O}_{4}$ Spinel-Type Catalysts for Deoxygenation of Palm Oil to Green Diesel. Chem. Eng. J. 2018, 345, 107-113.

(32) Cao, Y.; Shi, Y.; Bi, Y.; Wu, K.; Hu, S.; Wu, Y.; Huang, S. Hydrodeoxygenation and Hydroisomerization of Palmitic Acid over Bi-Functional Co/H-ZSM-22 Catalysts. Fuel Process. Technol. 2018, 172, 29-35.

(33) Kordouli, E.; Pawelec, B.; Bourikas, K.; Kordulis, C.; Fierro, J. L. G.; Lycourghiotis, A. Mo Promoted $\mathrm{Ni}-\mathrm{Al}_{2} \mathrm{O}_{3}$ Co-Precipitated Catalysts for Green Diesel Production. Appl. Catal., B 2018, 229, 139-154.

(34) Zhang, H.; Lin, H.; Zheng, Y. The Role of Cobalt and Nickel in Deoxygenation of Vegetable Oils. Appl. Catal., B 2014, 160-161, 415-422.

(35) Hachemi, I.; Kumar, N.; Mäki-Arvela, P.; Roine, J.; Peurla, M.; Hemming, J.; Salonen, J.; Murzin, D. Y. Sulfur-Free Ni Catalyst for Production of Green Diesel by Hydrodeoxygenation. J. Catal. 2017, 347, 205-221.

(36) Chen, N.; Gong, S.; Qian, E. W. Effect of Reduction Temperature of $\mathrm{NiMoO}_{3-\mathrm{x}} / \mathrm{SAPO}-11$ on Its Catalytic Activity in Hydrodeoxygenation of Methyl Laurate. Appl. Catal., B 2015, 174$175,253-263$.

(37) Kordouli, E.; Sygellou, L.; Kordulis, C.; Bourikas, K.; Lycourghiotis, A. Probing the Synergistic Ratio of the $\mathrm{NiMo} / \gamma$ $\mathrm{Al}_{2} \mathrm{O}_{3}$ Reduced Catalysts for the Transformation of Natural Triglycerides into Green Diesel. Appl. Catal., B 2017, 209, 12-22.

(38) Chen, H.; Wang, Q.; Zhang, X.; Wang, L. Effect of Support on the NiMo Phase and Its Catalytic Hydrodeoxygenation of Triglycerides. Fuel 2015, 159, 430-435.

(39) Nag, N. K. A Comparative Study on the Msperslon and CarrierCatalyst Interaction of Molybdenum Oxides Supported on Various Oxides by Electron Spectroscopy for Chemical Analysis. J. Phys. Chem. 1987, 91, 2324-2327.

(40) Wang, Y.; Xiong, G.; Liu, X.; Yu, X.; Liu, L.; Wang, J.; Feng, Z.; $\mathrm{Li}, \mathrm{C}$. Structure and Reducibility of $\mathrm{NiO}-\mathrm{MoO}_{3} / \gamma-\mathrm{Al}_{2} \mathrm{O}_{3}$ Catalysts: Effects of Loading and Molar Ratio. J. Phys. Chem. C 2008, 112, 17265-17271.

(41) Jeništová, K.; Hachemi, I.; Mäki-Arvela, P.; Kumar, N.; Peurla, M.; Capek, L.; Wärnå, J.; Murzin, D. Y. Hydrodeoxygenation of Stearic Acid and Tall Oil Fatty Acids over Ni-Alumina Catalysts: Influence of Reaction Parameters and Kinetic Modelling. Chem. Eng. J. 2017, 316, 401-409.

(42) Rozmysłowicz, B.; Kirilin, A.; Aho, A.; Manyar, H.; Hardacre, C.; Wärnå, J.; Salmi, T.; Murzin, D. Y. Selective Hydrogenation of Fatty Acids to Alcohols over Highly Dispersed $\mathrm{ReOx} / \mathrm{TiO}_{2}$ Catalyst. J. Catal. 2015, 328, 197-207.

(43) Yenumala, S. R.; Maity, S. K.; Shee, D. Reaction Mechanism and Kinetic Modeling for the Hydrodeoxygenation of Triglycerides over Alumina Supported Nickel Catalyst. React. Kinet., Mech. Catal. 2016, 120, 109-128.
(44) Zhou, L.; Lawal, A. Kinetic Study of Hydrodeoxygenation of Palmitic Acid as a Model Compound for Microalgae Oil over $\mathrm{Pt} / \gamma$ $\mathrm{Al}_{2} \mathrm{O}_{3}$. Appl. Catal., A 2017, 532, 40-49.

(45) Giordano, N.; Bart, J. C. J.; Vaghi, A.; Castellan, A.; Martinotti, G. Structure and Catalytic Activity of $\mathrm{MoO}_{3} \cdot \mathrm{Al}_{2} \mathrm{O}_{3}$ Systems: I. SolidState Properties of Oxidized Catalysts. J. Catal. 1975, 36, 81-92.

(46) Tian, H.; Wachs, I. E.; Briand, L. E. Comparison of UV and Visible Raman Spectroscopy of Bulk Metal Molybdate and Metal Vanadate Catalysts. J. Phys. Chem. B 2005, 109, 23491-23499.

(47) Ozkan, U.; Schrader, G. L. $\mathrm{NiMoO}_{4}$ Selective Oxidation Catalysts Containing Excess $\mathrm{MoO}_{3}$ for the Conversion of $\mathrm{C}_{4}$ Hydrocarbons to Maleic Anhydride. J. Catal. 1985, 95, 137-146.

(48) Liu, H.; Cheung, P.; Iglesia, E. Effects of $\mathrm{Al}_{2} \mathrm{O}_{3}$ Support Modifications on $\mathrm{MoO}_{\mathrm{x}}$ and $\mathrm{VO}_{\mathrm{x}}$ Catalysts for Dimethyl Ether Oxidation to Formaldehyde. Phys. Chem. Chem. Phys. 2003, 5, 37953800.

(49) Al-Ubaid, A.; Wolf, E. E. Steam Reforming of Methane on Reduced Non-Stoichiometric Nickel Aluminate Catalysts. Appl. Catal. 1988, 40, 73-85.

(50) Kordouli, E.; Pawelec, B.; Bourikas, K.; Kordulis, C.; Fierro, J. L. G.; Lycourghiotis, A. Mo Promoted Ni- $\mathrm{Al}_{2} \mathrm{O}_{3}$ Co-Precipitated Catalysts for Green Diesel Production. Appl. Catal., B 2018, 229, 139-154.

(51) Dhanala, V.; Maity, S. K.; Shee, D. Roles of Supports $\left(\gamma-\mathrm{Al}_{2} \mathrm{O}_{3}\right.$, $\mathrm{SiO}_{2}, \mathrm{ZrO}_{2}$ ) and Performance of Metals (Ni, Co, Mo) in Steam Reforming of Isobutanol. RSC Adv. 2015, 5, 52522-52532.

(52) Liu, J.; Liu, C.; Zhou, G.; Shen, S.; Rong, L. Hydrotreatment of Jatropha Oil over NiMoLa $/ \mathrm{Al}_{2} \mathrm{O}_{3}$ Catalyst. Green Chem. 2012, 14, 2499-2505.

(53) Liu, J.; Fan, K.; Tian, W.; Liu, C.; Rong, L. Hydroprocessing of Jatropha Oil over $\mathrm{NiMoCe} / \mathrm{Al}_{2} \mathrm{O}_{3}$ Catalyst. Int. J. Hydrogen Energy 2012, 37, 17731-17737.

(54) Hernández-Huesca, R.; Mérida-Robles, J.; Maireles-Torres, P.; Rodríguez-Castellón, E.; Jiménez-López, A. Hydrogenation and RingOpening of Tetralin on Ni and NiMo Supported on Alumina-Pillared $\alpha$-Zirconium Phosphate Catalysts. A Thiotolerance Study. J. Catal. 2001, 203, 122-132.

(55) Kukushkin, R. G.; Bulavchenko, O. A.; Kaichev, V. V.; Yakovlev, V. A. Influence of Mo on Catalytic Activity of Ni-Based Catalysts in Hydrodeoxygenation of Esters. Appl. Catal., B 2015, 163, 531-538.

(56) Li, C.; Chen, Y.-W. Temperature-Programmed-Reduction Studies of Nickel Oxide/alumina Catalysts: Effects of the Preparation Method. Thermochim. Acta 1995, 256, 457-465.

(57) Qu, L.; Zhang, W.; Kooyman, P. J.; Prins, R. MAS NMR, TPR, and TEM studies of the interaction of NiMo with alumina and silicaalumina supports. J. Catal. 2003, 215, 7-13.

(58) Taromi, A. A.; Kaliaguine, S. Green Diesel Production via Continuous Hydrotreatment of Triglycerides over Mesostructured $\gamma$ Alumina Supported NiMo/CoMo Catalysts. Fuel Process. Technol. 2018, 171, 20-30. 